\title{
I. DÜNYA SAVAŞI SONUNDAN CUMHURIYET'İN İLK YILLARINA KADAR HARP KAZANÇLARI VERGİSI (1919-1925)
}

\section{TAX OF WAR EARNINGS FROM THE END OF THE I. WORLD WAR TO THE FIRST YEARS OF THE REPUBLIC (1919-1925)}

Ali Rıza GÖNÜLLÜ*

\begin{abstract}
$\ddot{O} z$
I. Dünya Savaşı yıllarında ticari hayatta bir kısım tüccarlarda gayri meşru kazanç elde etme temayülü önemli ölçüde artmıştır. Buna mani olmak hususunda devlet, bazı tedbirler almıştır. Bunların başında elde edilen gelirlerden özel bir vergi tahsil edilmesi gelmektedir. Devlet bu vergiyi tahsil etmek için bazı hukuki düzenlemeler yapmıştır. Bu konuda ilk derli toplu çalışma merkezi yönetim tarafindan çıarılan 14 Aralık 1919 tarihli Harp Kazançları Vergisi Hakkında Kararname'dir. Bu kararname ile 1916, 1917 ve 1918 yillarmda elde edilen gelirlerden Harp Kazançları Vergisi alınması hükme bağlanmıştır. Ancak bu verginin mükelleflerden tahsil edilmesi, içinde bulunulan savaş şartlarından dolayı, mümkün olamamıştır. Harp Kazançları Vergisi'nin tahsil edilmesi konusunda Milli Mücadele Döneminde Ankara Hükümeti tarafindan bazı çalışmalar yapılmıştır. Bunun neticesinde adı geçen vergi ilk defa 1922'de devletin "gelirler bütçesinde" gösterilmiştir. Harp Kazançları Vergisi 1923, 1925 ve 1925'e ait gelirler bütçesinde de yer almıştır.
\end{abstract}

Anahtar Kelimeler

I. Dünya Savaşı, Milli Mücadele, Cumhuriyet, Karaborsacılık, Harp Kazançları Vergisi.

\section{Abstract}

In the First World War, the tendency to gain illegitimate profits in some merchants in commercial life has increased significantly. To avoid this, some measures have been taken by the state. The main of them is a special tax being charged from the obtained income. The state has made some legal arrangements to collect this tax. The first batch of work on this subject was 14 December 1919 dated, Decree on Tax of War Earnings issued by the central government. It was decided that Tax of War Earnings should be taken from the income obtained in 1916, 1917 and 1918 by this decree. However, this tax could not be charged from the taxpayers due to the conditions of war. Some studies have been done by the Ankara government on the collection of Tax of War Earnings. As a result, this mentioned tax was shown for the first time on the government revenues budget in 1922. The Tax of War Earnings is also included in the income budget of 1923, 1924 and 1925.

\section{Keywords}

I. World War, National Struggle, Republic, Black Marketeering, Tax of War Earnings.

Dr., Alanya Mesleki ve Teknik Anadolu Lisesi, argonullu@hotmail.com 


\section{GİRIŞ}

Savaş dönemleri milletlerin hayatında sosyal çözülmelerin meydana geldiği önemli devrelerdir. I.Dünya Savaşı sırasında da Osmanlı Devleti'nin içinde bulunduğu savaş hali, sosyal hayatta önemli insanî krizlerin ortaya çıkmasına sebep olmuştur. Bunların en önemlilerinden birisi ticari hayatta kendini göstermiştir. Bu dönemde bir kısım ticaret erbabında gayrimeşru kazanç elde etme temayülü görülmüştür. Merkezi yönetimin birçok mala narh koymasına karşın, karaborsa alıp yürümüş, kıtlığı çekilen her türlü mal el altından sağlanır olmuştur (Toprak 1982: 294). Karaborsacilık İstanbul dışında, taşrada da kendini göstermiş, yerel yönetimler karaborsanın önünü alabilmek için, kanunların kendilerine verdiği yetkiye dayanarak muhtelif tedbirler almaya çalı̧̧ışlardır (Alaiye Belediye Meclisi Karar Defteri 1330-1331: 1). Bununla birlikte merkezi ve mahalli idareler tarafından alınan bütün tedbirler, karaborsacıllğg önleyememiştir. Bilakis ticari hayatta meydana gelen bu yozlaşma sosyal hayatta, "harp zengini" deyiminin doğmasına sebep olmuştur (Demiryürek 2015: 496).

Hükümet, karaborsaya mani olmak için 24 Mayıs 1917'de 281 Numaralı İhtikârın Men'i Hakkında Kanun-1 Muvakkat'i kabul etmiştir. 14 maddeden meydana gelen bu geçici kanunda;

“Harp hali neticesi ortaya çıkan fevkalade ahvalden istifade ederek, serbest bir arz ve talep ile eşyanın takarrür edecek fiyatını yükselterek, kazanmak kastıyla alış veriş kanunen ihtikâr addolunur. Piyasada mevcut eşyanın fiyatına tesir edecek derece de yed-i vahdette cem' etmek suretiyle mubayaası veya satın aldıktan sonra fiyatının arttırılmasına sebep olacak surette elden ele dolaşması dâhi ihtikârdan sayılmıştır (Madde 1)" (Düstur 1928: 9/687), denilerek ihtikâr suçu tarif edilmiştir.

Bu geçici kanun İhtikâr'ın Men'i Heyeti teşkil edilmesini de hükme bağlamıştır. Şöyle ki; İhtikâr cürümü hakkında takibat ve tetkikatta bulunarak, muhtekirleri Divan-ı Harbi Örfilere tevdi etmek ve İaşe Heyeti'nin meşgul olduğu hususlardan başka ihtiyaçlarm tedarik suretini ve mubayaa tarzını tayin ederek, ihtikârın meni hakkında tedbirleri almak üzere Dâhiliye Nazırı'nın başkanlığında bir Men-i İhtikâr Heyeti kurulacaktır (Madde 2, 10) (Düstur 1928: 9/687).

Meni Heyeti'nin gerçekleştirmek zorunda olduğu bazı görevler vardır. Bu görevlerden bazıları şunlardır:

Ne miktardaki satın almaların toptan, ne miktardaki satın almaların perakende satış olduğunun tayin edilmesi, toptan satış için bir muayyen mahal göstererek o mahal haricinde meydana getirilecek satın almaları yasaklaması, tüccarın perakende surette satılacak eşya üzerinde fiyatları açık bir şekilde göstermeye mecbur edilmesi, toptan olarak elde mevcut olan eşyanın muhafaza olunacakları arazilerin tayin edilmesi, muayyen bir müddet zarfında iş bu arazilere depo edilmeyen eşyayı heyetin murakabesinden kaçırılmış kabul ederek zapt edilmesi ve icap ettiği takdirde perakende satılacak eşyaya azami ölçüde bir fiyat takdir edilmesi gibi hususlardır (Madde5-6) (Düstur 1928: 9/686-687).

Men'i Hakkında Kanun-ı Muvakkat, ticaret erbabına da bazı görevler yüklemiştir. Bu görevler arasında şunlar bulunmaktadır.

Men-i İhtikâr Heyeti'nce listesi ilan olunacak eşyaya malik olanlar veya bu eşyayı başkaları nam ve hesabına hıfz ve idare edenler eşyanın miktar ve nevini heyete bildirmeğe mecburdurlar. Başkaları namına eşyayı hıfz edenler eşyanın sahiplerini de bildirmeğe 
mecburdurlar. Tüccardan veya esnaftan herkesin bir malı ilk mubayaa ettiği zaman ne fiyat üzerinden satış yapmış ise o malın aynını bu gün aynı fiyata tedarik kabil olmasa dahi mevcudu tüketinceye kadar, ilk tensip ettiği fiyat mucibince satış yapmaya devam edilecektir. $\mathrm{Bu}$ kanunun neşir tarihinden itibaren bilcümle tüccar ve esnaf ellerindeki malların fiyatını derhal ilk vaz' ettikleri seviyeye tenzil edeceklerdir. Kendilerinden talep edilen malumatı ita etmeyenler veya eşya miktarını aşağı olarak bildirenler, depolarını gizleyen veya malların imha edenler ve heyetin ittihaz edeceği tedbirleri akim bırakmak üzere bir takım vasıtalara müracaat edenlerin malları zapt olunacaktır. Kendileri üç aydan üç seneye kadar hapis ve yüz liradan beş bin liraya kadar peşin parası ödemeye mahkûm edileceklerdir (Madde 8-10) (Düstur 1928: 9/688).

İhtikârın Men'i Hakkında Kanun-u Muvakkat'in yürürlüğe girmesinden sonra Sadrazam ve Dâhiliye Nazırı Talat Paşa'nın başkanlığında Mebusan Meclisi Reis Vekili Hüseyin Cahit Bey, Dâhiliye Nezareti Hukuk Müşaviri Osman Bey, İttihat ve Terakki Cemiyeti Genel Merkez üyelerinden Doktor Nazım ve Resuhi beylerden oluşan Men-i İhtikâr Heyeti kurulmuştur (Toprak 1982: 295). Ancak adı geçen heyetin faaliyete geçmesi, beklenen neticeyi vermemiş, heyetin faaliyette bulunduğu ilk altı ay içerisinde fiyat artış hızı düşeceğine yükseliş kaydetmiştir. Ocak 1917'den Haziran 1917'ye kadar tüketici geçinme endeksi 405 puandan 670 puana yükselerek 265 puanlık bir artış gösterirken, Men-i İhtikâr Heyeti'nin faaliyete geçtiği 1917 yılının Haziran ayından 1918 yılı başına kadar 670 puandan 1.645 puana ulaşarak, 975 puanlık bir artış göstermiştir (Toprak 1982: 301-302).

Karaborsacılıkla yapmış olduğu mücadelede önemli bir sonuç alamayan hükümet, ticari hayatta ortaya çıkan haksız kazancın varlığını kabul ederek, bu gelirin vergilendirilmesi için yeni bir adım atmıştır. Bunun için 1917 sonlarına doğru o sıralarda Almanya, AvusturyaMacaristan ve Fransa gibi memleketlerde uygulanmaya başlanan Harp Kazançları Vergileri örnek alınarak, vergi mükelleflerinden Harp Kazançları Vergisi ismini taşıyan olağanüstü bir verginin tahsil edilmesi hususunda hukuki bir çalışma başlatmıştır (Toprak 1982: 302).

Burada Harp Kazançları Vergisi üzerinde durularak, Türk vergi sistemindeki yeri gösterilmeye çalışılacaktır¹.

Konu şu başlıklar altında incelenecektir:

1.Milli Mücadele ve Cumhuriyet Döneminde Harp Kazançları Vergisi Matrahı ve Tahsili 1.1.Hukuki Düzenlemeler

1.1.1.İstanbul Şehremaneti'nin Harp Kazançları Vergisi'nden Hisse Talebi

1.2.Bütçe Gelirleri'nde Harp Kazançları Vergisi Miktarı

1.3.Harp Kazançları Vergisi'nin Tecil Edilmesi ve Alınmaması

1.4.Harp Kazançları Vergisi'nin Terkini

1.5.Yabancı Devlet Vatandaşları'ndan Harp Kazançları Vergisi'nin Alınması

\section{MILLLI MÜCADELE ve CUMHURIYYET DÖNEMINDE HARP KAZANÇLARI VERGİSI MATRAHI VE TAHSİLI}

\subsection{Hukuki Düzenlemeler}

Mütareke ve Milli Mücadele dönemi ile Cumhuriyetin ilk yıllarında Harp Kazançları Vergisi konusunda birçok hukuki düzenleme yapılmıştır. Bu konuda yapılan ilk düzenleme İstanbul Meclisleri tarafından kabul edilen 4 Nisan 1918 tarihli ve 126 numaralı Harp Kazançları

1 Harp Kazançları Vergisi ile ilgili olarak şu eserlerde bazı bilgiler bulunmaktadır; (Eldem 1994: 92-94, 195; Tezcan, 2005: 47- 49). 
Vergisi'nin Temin-i tahsili İçin Tedabir-i evveliyeyi muhtevi kanundur. Bu kanun 8 maddeden meydana gelmiştir (Düstur 1928: 10/422-423).

Bu kanunla; Osmanlı Devleti dâhilinde faaliyet gösteren bütün anonim şirketler, anonim şeklinde olan kooperatifler ve sermayeleri hisse senetlerine bölünmüş olan komandit şirketler 31 Aralık 1917'de veya muahhar bir tarihte hitam bulan ticaret senelerine ait kârlarını tevzi edecekleri sırada bir ihtiyat akçesi ayırmak zorunda bırakılmıştır. Adı geçen şirketler kâr olarak ortaya çıan miktardan, ilk önce tediye edilmiş sermayenin faizi ile gelir hissesi mukabili olmak ve her ikisinin toplamı adı geçen sermayenin \%15'i geçememek şartıyla genel meclislerince uygun görülecek meblağı düşecektir. Daha sonra nizamnameleri gereği tespit edilen adi ihtiyaç akçesini, yine kârlardan kuruculara, idare meclisi azalarına, müdür ve memurlara ayrılacak olan hisseleri veya ikramiyeleri, hayır cemiyetlerine verilecek olan payları ve iptidai tesisatın imhası karşılığı olan kısmı ayıracaklardır. Bu işlemden sonra da elde kalan kârlarını, harp kazançları üzerine bir vergi tarhına özel bir kanun ile karar verildiği takdirde, tahakkuk edecek olan vergi borçlarını karşılayabilmek için bir ihtiyat akçesi olarak muhafaza edecekleri hükme bağlanmıştır (Düstur 1928: 10/422).

Harp Kazançları Vergisi hakkında geniş kapsamlı ilk hukuki düzenleme, merkezi hükümet tarafından yayınlanan 14 Aralık 1919 tarihli Harp Kazançları Vergisi Hakkında Kararname'dir. Bu kararname 7 fasıl ve 40 maddeden meydana gelmiştir (Harp Kazançları Vergisi Hakkında Kararname 1335: 1-24; Düstur 1928: 11/495-511).

Bu kararnamede, Umumi harp esnasinda istihsal edilen fevkalade gelir üzerine "Harp Kazançlarn Vergisi" namı ile bir defaya mahsus olarak fevkalade bir vergi tesis edilmiştir. Bu vergi 1332 "1918" senesi aralık ayı nihayetine kadar hitam bulan son üç ticari sene zarfinda vuku bulan fevkalade gelir üzerine tarh olunur (Madde 1), denilerek, verginin tarifi, kapsamı ve mükellefiyet zamanı ortaya konulmuştur (Harp Kazançları Vergisi Hakkında Kararname 1335: 3).

Bununla birlikte bu kararname ile bir kısım meslek mensubu Harp Kazançları Vergisi kapsamı dışına çıkarılmıştır. Adı geçen vergiden muaf tutulan meslek mensupları şunlardır:

“Dükkân ve mağaza açmaksızın mahsullerini çiftliğinde veyahut şehir ve kasabalarda veya pazar yerlerinde satan çiftlik sahipleri ve bir sene zarfında satmış oldukları tütün bedelleri yüz liradan aşağı olan tütün çiftçileri ile sair bilumum çiftçiler ve kendi hayvanlarını besleyen mandıra sahipleri ve çoban ve bağclar ve bahçıvanlar.

Kendi hesaplarına ticaret yapmamak şartıyla özel müesseselerde ve kişilerin hizmetlerinde maktu maaş veya ücretle müstahdem olanlar.

Kendi el emekleri ile maişet tedarik eden bilumum amele ve işçiler (Bunlardan hamal ve arabacılar istisna tutularak dokuzuncu ve muhtelif limanlar arasında gidiş-geliş yapan kayıkçılar onuncu madde mucibince maktu vergi ile mükelleftirler.)

Müellif ve muharrirler, ressamlar, heykeltıraşlar, bestekârlar, kompozitör mühendisler, mimarlar, tabipler, dava vekilleri, cerrahlar, ebeler, dişçiler, baytarlar ve alelumum ilmi ve fenni üstünlükleri ile maişet kazananlar (Dava vekillerinin hukuk müşavirliği ücreti olarak herhangi bir müesseseden senelik aldıkları meblağ 500 liradan ziyade ise fazlası harp temetttuatı addolunacağ $\breve{1}_{1}$ gibi, mühendislerin ve mimarların deruhte eyledikleri inşaat 5.000 lirayı tecavüz eylediği takdirde fazlasından müstahsil temettu dahi harp temettuatından addedilir.)

Matbaacılar, Taş ocaklarını işletenler, Aşar ve rüsum-ı saire mültezimleri.

Kira bedeli yılllı 3.500 kuruşu aşmayan değirmenleri işletenler.

Sahillerde ve demiryolu istasyonlarında bulunanlar müstesna olmak üzere nüfusu 
2.000'den aşağı olan köyler ahalisi.

Son harpte düşman tarafından işgal edilen mahallerden hicret edenler ile genel olarak ahir mahallere nakil ve tehcir edilenler.

Yangın ve hayat sigorta şirketleri (Nakliyat sigorta şirketleri on beşinci madde mucibince vergiye tabidirler.) (Madde 2)" (Harp Kazançları Vergisi Hakkında Kararname 1335: 3-4).

Kararname'de Harp Kazançları Vergisi'nin, maktu ve müterakki olmak üzere iki kısma ayrıldığı görülmektedir. Maktu vergi; özel kanununa göre alınmakta olan bazı vergilerin bir veya birkaç misli olarak tarh edilmesidir. Müterakki vergi ise; alışılmış gelirin üzerinde ortaya çıkan fevkalade gelirden, müterakki nispetle tarh olunan fevkalade bir vergidir (Madde 8) (Harp Kazançları Vergisi Hakkında Kararname 1335: 6).

Harp Kazançları Vergisi Kararnamesi'ne göre, 1918 senesinde adına tahakkuk ettirilen temettu vergisi 2.500 kuruşu geçmeyenler maktu vergi ile mükellef tutulur. Temettu vergisi 1.500 kuruşu geçmeyenlerden adı geçen verginin üç misli, temettu vergisi 1.500 kuruştan fazla olanlardan, fakat 2.500 kuruşu geçmeyenlerden adı geçen verginin altı misli maktu vergi tahsil edilir (Madde 8, 9) (Harp Kazançları Vergisi Hakkında Kararname 1335: 6-7).

Ancak müterakki vergiyi hesaplamak için bazı yollar izlenmektedir. Şöyle ki; anonim, kooperatif ve hisseli komandit şirketlerin mükellefiyet müddeti olan son üç ticari seneden, her biri için tanzim etmiş oldukları bilançolar gereği tebeyyün eden kârlarından; nizamnameleri gereği senelik ödenmesi gereken faiz, senelik ihtiyat akçesi miktarı, ibtidai tesisat imhası karşılığı, tahsisleri nizamnamede belirtilmiş olan diğer miktarlar ve temettu hissesi olmak üzere sermayenin ödenmiş olan kısmından ayrılan yıllık \% 5’lik kısım düşülür. Bu işlem yapıldıktan sonra, geri kalan kâr miktarı fevkalade gelir olarak kabul edilir ( Madde 4) ( Harp Kazançları Vergisi Hakkında Kararname 1335: 5). Adı geçen şirketlerin bu şekilde hesaplanarak ortaya çıkmış olan fevkalade gelirleri, aşağıdaki gösterildiği gibi müterakki nispetle Harp Kazançları Vergisi'ne tabi tutulur (Madde 11) (Harp Kazançları Vergisi Hakkında Kararname 1335: 7).

Tablo 1; Anonim, Kooperatif ve Hisseli Komandit Şirketlere Uygulanacak Müterakki Nispeti.

\begin{tabular}{|l|l|}
\hline Miktar (Kuruş) & $\%$ \\
\hline 1.000 & 5 \\
\hline $1.001-5.000$ & 10 \\
\hline $5.001-10.000$ & 15 \\
\hline $10.001-25.000$ & 20 \\
\hline $25.001-50.000$ & 30 \\
\hline $50.001-100.000$ & 40 \\
\hline $100.001-250.000$ & 50 \\
\hline $250.001-$ & 60 \\
\hline
\end{tabular}

Bunun yanında kolektif ve adi komandit şirketlerle, muhtelif kişilerin matrah temettu vergilerinin aslı senelik 2.500 kuruşu geçenler de müterakki nispetle vergiye tabi tutulur. Adı geçen kurum ve kişilerin fevkalade gelirleri şu şekilde hesap edilir (Harp Kazançları Vergisi Hakkında Kararname 1335: 7).

1916, 1917 ve 1918 senelerinden her birinde mükellefe tarh edilmiş olan temettu vergisinin aslı 33 ile çarpılır. Bulunacak neticeye, bunun 1/4 'ü eklenir. Bu miktara senelik maktu olarak 350 lira hesabı ile 1.050 lira ilave edilir. Ortaya çıkan tutar, mükellefin adı geçen senelere ait normal 
kazancı olarak kabul edilir. Bu miktar, adı geçen seneler için mükellefin tanzim etmiş olduğu bilançolar gereği tebeyyün eden kârının toplamından çıkarılır. Böylece geri kalan miktar harp kazançları vergisine tabi tutulması gereken, üç senelik fevkalade geliri meydana getirmiş olur (Madde 7) (Harp Kazançları Vergisi Hakkında Kararname 1335: 7).

Kolektif ve adi komandit şirketlerle, muhtelif kişilerin fevkalade gelirleri de aşağıdaki gösterildiği gibi müterakki nispetle Harp Kazançları Vergisi'ne tabi tutulur (Madde 12) (Harp Kazançları Vergisi Hakkında Kararname 1335: 7).

Tablo 2; Muhtelif Kişilerle, Kolektif ve Adi Komandit Şirketlere Uygulanacak Müterakki Nispeti.

\begin{tabular}{|l|c|}
\hline Miktar (Kuruş) & $\%$ \\
\hline 1.000 & 10 \\
\hline $1.001-5.000$ & 15 \\
\hline $5001-10.000$ & 20 \\
\hline $10.001-25.000$ & 25 \\
\hline $25.001-50.000$ & 30 \\
\hline $50.001-100.000$ & 40 \\
\hline 100.000 & 50 \\
\hline $250.001-$ & 60 \\
\hline
\end{tabular}

Harp Kazançları Vergisi Kararnamesi'ne göre, Harp Kazançları Vergisi'nin maktu kısmının bir ay ara ile iki taksitte, müterakki kısmının da ikişer ay ara ile üç taksitte Tahsil-i Enval Kanunu'na ${ }^{2}$ uygun olarak tahsil edileceği beyan edilmiştir (Madde 29) (Harp Kazançları Vergisi Hakkında Kararname 1335: 21).

Adı geçen kararnamenin yayınlanmasından sonra, 7 fasıl, 72 madde ve 10 ekten meydana gelen Harp Kazançları Vergisi Hakkındaki Kararname'nin Suver-i Tatbikiyesini Mübeyyin Talimatname neşredilerek, Harp Kazançları Vergisi'nin tahsil edilmesi süresince yapılacak olan işlemler izah edilmiştir (Harp Kazançları Vergisi Hakkındaki Kararname'nin Suver-i Tatbikiyesini Mübeyyin Talimatname 1335: 3 vd).

Ancak 29 Şubat 1920'de Meclisi-i Mebusan ve Meclis-i Ayan'da kabul edilen 1920 senesi Mart ve Nisan aylarına mahsus Muvakkat Bütçe Kanunu'nun 3. Maddesi'nde Harp Kazançları Vergisi'nin tahsil edilmesi ile ilgili bir istisna getirilmiştir. Bu kanunda;

1918 senesi Muvazene-i Umumiye Kanunu ile bunun neşrinden sonra neşir olunan ve Kavanin ve Kararnamelere müsteniden Devletçe istifa olunmakta bulunan rüsum ve tekâlifin 1920 senesi Mart ve Nisan ayları zarfında cibayat ve tahsiline devam olunacaktır. Yalnız Harp Kazançları Hakkındaki Kararname, Meclisçe müzakere ve tasdik edilinceye kadar, bu kararname mucibince tahakkuk ettirilecek vergilerin tahsili tecil olunacaktır

denilerek, Harp Kazançları Vergisi'nin tahsil edilmesi ertelenmiştir (Meclis-i Mebusan Zabıt Ceridesi 1992: 158 vd; Meclis-i Ayan Zabit Ceridesi 1991: 149 vd).

Milli Mücadele döneminde, Harp Kazançları Vergisi'nin Tahsiline Dair bir kanun tasarısı hazırlanmıştır. Bu kanun tasarısında; 1920 senesi Mart ve Nisan ayı Muvakkat Bütçe Kanunu'yla tahsili tecil edilmiş olan Harp Kazançları Vergisi tahsiline devam edilecektir. İş bu kanunun her mahalde neşir tarihi ve ilanından sonra geçerli (Madde 1-2)" olduğu ifade edilmiştir. Ancak adı geçen kanun tasarısı, Türkiye Büyük Millet Meclisi'nde görüşülmeyerek kanunlaşmamıştır (BCA, BKK

25 Ağustos 1325/18 Ağustos 1909 tarihli Tahsil-i Emval Kanunu ve bu kanunda yapılan değişiklikler Osmanlı Devleti'nden Cumhuriyet dönemine de intikal etmiş ve belli bir süre yürürlükte kalmıştır. Dört fasıl ve 23 maddeden meydana gelen bu kanunun ilk metni için bakınız; (Tahsil-i Emval Kanunu 1325:1-7) 
30.18.01: 01.11.26). Ancak bir müddet sonra Türkiye Büyük Millet Meclisi tarafından 25 Ekim 1920 tarihinde yukarıda bahsedilen kanun tasarısının ismini taşıyan, fakat muhtevası farklı olan 43 Numaralı Harp Kazançları Vergisi'nin Tahsili'ne Dair Kanun kabul edilmiştir. Bu kanunla, "Harp Kazançları Vergisi Kanunu mucibince tahsilât yapılabilmesi için Maliye Vekâleti'ne izin verilmiştir" (Türkiye Büyük Millet Meclisi Kavanin Mecmuası 1341: 1/59).

Şubat 1922 tarihinde de 192 Numaralı 1922 Senesi Emlâk ve Temettu Vergileriyle Ağnam Resmi'nin ve Harp Kazançları Vergisi'nin Suret-i Tahsiline Dair Kanun, Türkiye Büyük Millet Meclisi'nde kabul edilmiştir. Bu kanunla;

Özel kanunlarına tevfikan muayyen taksitlerde istifa edilmekte olan Emlâk ve Temettu Vergileri ile Ağnam Resmi ve küsurat-ı munzamları 1922 senesine mahsus olmak üzere, adı geçen yılın Mart ayından itibaren bir defada tahsil olunur. Küsurat-ı munzamlar tahsil edildikten sonra doğrudan doğruya mahallindeki ziraat bankalarına tevdi olunur. 25 Ekim 1920 tarihli kanun ile kabul olunan Harp Kazançları Vergisi'nden tahakkuk eden miktarlar dahi birinci madde veçhile bir defada tahsil olunur. (Türkiye Büyük Millet Meclisi Kavanin Mecmuası 1338-1341: 2/194), hükmü getirilmiştir.

9 Mayıs 1922 tarihinde kabul edilen 231 Numaralı Harp Kazançları Vergisi Kanunu'nun 27. Maddesi'nin I. Fıkrasını Muadil Kanunla da tahakkuk eden Harp Kazançları Vergisi'ne yapılacak itirazları görüşmek üzere, kurulacak olan Merkez Komisyonu'nun teşkil edilme şekli hükme bağlanmıştır. Bu kanuna göre; Harp Kazançları Vergisi itiraz belgelerini tetkik edecek Merkez Komisyonu'nun bir reis ile altı azadan meydana geleceği ve reis ile azadan ikisinin Maliye ve ikisinin İktisat Vekâletleri memurlarından olmak üzere adı geçen vekâletlerce, diğer ikisinin de Ticaret Odası azalarından oda tarafindan seçileceğ i tespit edilmiştir (Türkiye Büyük Millet Meclisi Kavanin Mecmuası 1338-1341: 3/84).

23 Ağustos 1922 tarihinde kabul edilen 251 numaralı Harp Kazançları Vergisi'nin Tahsiline Dair Olan 25 Ekim 1920 Tarihli Kanuna Tezyil Edilen Kanunla da şu değişiklikler yapılmıştır:

Bidayet Tarh Komisyonları'nca talep olunan beyannameyi vermeyenler veya gerçek dışı beyanname verenler için 14 Aralık 1919 tarihli Kararname'nin 18, 21, 22'nci maddeleri mucibince zammedilen cezaların hepsi ilga edilmiştir. Adı geçen madde mucibince beyanname ita olunmamasından veya gerçek dışı beyanatta bulunmasından dolayı Bidayet Tarh Komisyonları'nca tahkikata müsteniden ve resen takdir olunan temettuat-1 safiye ile mükellef tarafından iş bu kanunun neşir tarihinden itibaren bir ay zarfında mükellefiyet seneleri içinde tuttuğu ticari defterlere istinaden yeniden verilecek beyanname muhteviyatı Temyiz Komisyonları'nca resen tetkik ve tarafların beyan ve takdirlerine göre hâsıl ettiği kanaat dairesinde ittihaza karar olunur. Ticari defterlere müstenit olmayan beyanname muteber değildir. Merkez Temyiz Komisyonu'nca tetkik edilerek kısmen veya tamamen tasdik olunan vergilere ceza olarak hiçbir şey zam olunamaz. 14 Aralık 1919 tarihli Kararname'nin iş bu eklenen maddelere muhalif olan ahkâmı ortadan kaldırılmıştır (Türkiye Büyük Millet Meclisi Kavanin Mecmuası 1338-1341: 3/122).

Milli Mücadele döneminde Harp Kazançları Vergisi'nin tahsil edilmesinde de bazı problemler ortaya çıkmıştır. Bunların çözümü için Maliye Vekâleti tarafından Türkiye Büyük Millet Meclisi Başkanlığı'na başvurularak, Harp Kazançları Vergisi Kararnamesi'nin bazı maddelerinin tefsir edilmesi talep edilmiştir. Mesela; Maliye Vekâleti tarafından 12/13 Haziran 1922 tarihinde Türkiye Büyük Millet Meclisi Başkanlığı'na bir yazı gönderilmiştir. Bu yazıda şu hususlara dikkat çekilmiştir: 
Harp Kazançları Vergisi Hakkındaki Kararname'nin 26. Maddesi'nde Tarh Komisyonları'nca takdir edilen vergiye, mükellefler tarafından verilecek olan itiraz dilekçelerinin mahallin en büyük mal memuruna tevdi edileceği belirtilmişti. Bununla birlikte bu dilekçelerin bulunan makama veya doğrudan doğruya Maliye Vekâleti'ne gönderilmesi uygun olmadığı halde, Merkez Komisyonu'nca tetkik edilmekte olan itiraz dilekçelerinden bazılarının mükellefler tarafından doğrudan doğruya mahallin mülkiye memuruna verilerek Muhasebe'ye havale edilmiş olduğu görülmüştü. Ancak kanunun emrettiği makamdan başkasına verilen itiraz dilekçeleri kanuni müddet zarfında verilmiş olsa bile, nazar-1 itibara alınmaması lazım geldiği halde, mükelleflerin çoğunluğu, bu kanun hükmüne vakıf değillerdi. Ayrıca mükellefler tarafından verilen itiraz dilekçelerinin mülkiye memurları tarafından esasen kabul edilmeyerek, görevli makama verilmesi gerektiğini dilekçe sahibine ihtar edilmesi gerekiyordu. Bunun yanında adı geçen makamlar tarafından bu cihete dikkat edilmediği, dilekçelerin kabul ve havale edilmesiyle görülüyordu. Mükelleflerin itiraz dilekçelerini görevli makama vermemelerinden dolayı, itiraz hakkının kullanılmaması ortaya çıkmakta, bu durum da uygun görülmemektedir. Ancak İdare-i Umumiye-i Vilayet Kanunu'nun 20. ve 21. Maddeleri hükmünce valiler vilayette icra kuvvetinin en büyük memuru, her vekâletin vekil ve mümessili olmalarından dolayı, kendilerine tevdi ve bahşedilmiş olan bütün vazifeleri yerine getirmekle görevlidir. Mutasarrıf ve kaymakamlar da aynı vaziyettedir. Şimdiye kadar müracaat sahipleri tarafından verilmiş olan dilekçelere, hep bu makamlar tarafından aracılık edilmiştir. Mülkiye memurları tarafından itiraz dilekçeleri kanuni süresi içinde, mal memuruna havale ve tevdi edilmiş olduğu ortaya çıtı̆̆ takdirde, tetkik mevkisi olan Merkez Komisyonu'nca ekseriyetle uygun görülmüştür. Buna rağmen konu hakkında tefsire ihtiyaç duyulmaktadır. $\mathrm{Bu}$ nedenle kanunun tayin ettiği makamdan başkasına verilmiş olan itiraz dilekçelerinin kabul edilmesi veya kabul edilmemesi konusunda Özel Encümen'ce bir karar verilmesi için gerekli işlemin yapılması gerekmektedir" (BCA, MUAMELAT 030.10.00: 135.968.08, L.1-2).

Maliye Vekâleti'nin bu talebi üzerine, Türkiye Büyük Millet Meclisi'nin 12 Kasım 1925'te yapmış olduğu toplantıda alınan kararda şöyle denilmektedir: Mahallin en büyük mülkiye memurları icra kuvvetinin reisidir. Bunun yanında bu makamlara yapılacak olan müracaatları men edecek bir kanun hükmü mevcut değildir. Bu nedenle mahallin en büyük mülkiye memurlarına yapılan müracaatların kanuna uygun olduğuna karar verilmiştir. Daha sonra alınmış olan bu karar, Türkiye Büyük Millet Meclisi Başkanlığı tarafından, 15 Kasım 1925'te Başvekâlet'e gönderilmiştir (BCA, MUAMELAT 030.10.00: 135.968.08, L.3).

Başvekâlet de 18 Kasım 1925'te adı geçen karar hakkında, Maliye ve Dâhiliye Vekâletleri'ne bilgi vermiştir (BCA, MUAMELAT 030.10.00: 135.968.08, L.4). Bunun yanında Harp Kazançları Vergisi Hakkındaki Kararname'nin 16. Maddesi'nin 8. Fıkrası'nda, uhdelerine 1.000 liralıktan fazla kıymette gayrimenkul mal geçirenlerin teferrug ${ }^{3}$ etmiş oldukları gayrimenkul malın kıymetinin 1.000 liradan fazlası harp temettuatından müstahsil ad olunarak 3. Maddedeki müterakki nispet üzerinden vergiye tabi tutulacağı yazılı bulunuyordu. Bu nedenle Harp Kazançları Vergisi Tarh Komisyonları tarafından tapu idarelerinden alınan kayıt ve defterlere istinaden mükellefiyet seneleri zarfında gayrimenkul mal teferrug edenlerin hepsine bu maddeye göre vergi tarh oluyordu. Bu mesele hakkında Maliye Vekâleti şu görüşe sahipti:

“Bu kanun fıkrası mutlak olarak yazılmış olmasına binaen, gayrimenkul mal teferrug edenlerin ayrım yapılmadan vergiye tabi tutulmaları görünüşte doğru gibi görünmektedir. Esasen bu vergi Harp Kazançları Vergisi namına haiz olmasına ve kararnamenin 16.

${ }^{3}$ Satın alınan bir mülkün ferağ muamelesini yaptırma, tapusunu kendi üzerine çevirme. (Devellioğlu 1998: 1057) 


\begin{abstract}
Maddesi'nin ilk fıkrasında gerek muafiyete haiz olan, gerek olmayan aşağıda yazılı muameleleri icra etmiş olanlar harp kazançlarına nail olmuş kabul edilerek, temettuat miktarlarını inandırıcı bir surette ispat edemedikleri takdirde, aşağıdaki özel karinelere istinaden mükellef tutulurlar denilmiştir. Buna göre bu vergi ile teklif edilecek şahısların ticaretle iştigal eden temettuat erbabından olması ve harp kazancı istihsal eylemiş bulunması lazımdır. Bunun yanında ticaretle iştigal etmesi kanunen yasak olan devlet memurları ile şimdiye kadar ticaretle meşgul olmayan kadınların, mükellefiyet seneleri zarfında gayrimenkul mal teferrug etmesi sebebi ile vergiye tabi tutulmaları kanunun maksadına uygun düşmemektedir. Merkez Komisyonu'nca itiraz evrakının tetkik edilmesi sırasında teferrug bedelleri üzerinden matrah vergilere, bilhassa kadınlar tarafından verilen itiraz dilekçelerinin hemen hepsinde ticaretle meşgul olmadıklarından ve harp kazancı istihsal etmediklerinden bahsedilerek, matrah vergiye itiraz edilmektedir. Bundan dolayı ticaretle meşgul oldukları resmi surette sabit olanlar müstesna olmak üzere, diğerlerinin bu vergiden istisna edilmeleri uygun görülmektedir" (BCA, MUAMELAT 030.10.00: 20.114.19, L.1).
\end{abstract}

Maliye Vekâleti, ticaretle iştigal etmeyen kadınlardan bu verginin tahsil edilmesi halinde, şu neticelerin ortaya çıabileceğini düşünüyordu:

Bunlardan birisi, Harp Kazançları Vergisi'nin tahsil edilebilmesi için teferrug olunan malın, hâlâ teferrug edenin tasarrufu altında ise satılarak kendisinin meskensiz kalmasına ve şiddetli yoksulluğa uğramasına sebep olmasıdır. Diğeri ise, adı geçen malın daha evvel satılmış olması halinde, adı geçen verginin tahsil edilmesi için bu kısım mükelleflerin hapis veya sair surette tazyik edilmeleri gerekecektir. Bu durumda olan mükelleflerin de hükümet tarafından iaşe edilmeleri lazım gelecektir. Bu suretle vergi borçlarını ifa edemeyecek olan mükelleflerin vergileri de bakayada kalmakla beraber, Hazine bunların iaşe masrafını ödemek suretiyle ayrıca zarara uğraması halidir"( BCA, MUAMELAT 030.10.00: 20.114.19, L.1).

Bu gerekçelerle Maliye Vekâleti tarafından 9 Nisan 1924 tarihinde Başvekâlet'e gönderilen tezkerede, ticaretle meşgul oldukları sabit olmayan memurlar ile kadınların Harp Kazançları Vergisi ile mükellef tutulmalarının kanunun maksadına ve adalete uygun olmadığı ifade edilerek, adı geçen kararnamenin 18. Maddesi ile bu maddenin 8. Fıkrası'nın Meclisçe tefsir edilmesi talep edilmiştir (BCA, MUAMELAT 030.10.00: 20.114.19, L.1).

Maliye Vekâleti'nin bu talebi, Başvekâlet tarafından 13 Nisan 1924 tarihinde Türkiye Büyük Millet Meclisi Başkanlığı'na gönderilerek, keyfiyetin tefsire ihtiyaç duyulduğu ve bu durumun acilen yapılması istenmiştir (BCA, MUAMELAT 030.10.00: 20.114.19, L.2-4).

Ancak Maliye Vekâleti 31 Ekim 1926'da Başvekâlet'e gönderdiği başka bir yazıyla; mükellefiyet senelerinde gayrimenkul mal teferrug etmiş olanların Harp Kazançları Vergisi ile mükellefiyetleri hakkındaki tefsir talebini, hiçbir gerekçe ileri sürmeden Türkiye Büyük Millet Meclisi'nden geri çekilmesini istemiştir (BCA, MUAMELAT 030.10.00: 20.114.19, L.5-6).

Başvekâlet de 27 Ekim 1926'da Türkiye Büyük Millet Meclisi'ne gönderdiği yazıda, Maliye Vekâleti'nin bu talebinin yerine getirilmesi için gerekli işlemin yapılmasını istemiştir (BCA, MUAMELAT 030.10.00: 20.114.19, L.7). Bunun üzerine Türkiye Büyük Millet Meclisi Başkanlığı, Maliye Vekâleti'nin adı geçen tefsir talebini 14 Aralık 1926 tarihinde Başvekâlet'e iade etmiştir (BCA, MUAMELAT 030.10.00: 20.114.19, L.8). Tefsir talebinin Türkiye Büyük Millet Meclisi Başkanlığı tarafından iade edildiği, Başvekâlet tarafından 14 Aralık 1926 
tarihinde Maliye Vekâleti'ne bildirilmiştir (BCA, MUAMELAT 030.10.00: 20.114.19, L.9).

\subsection{1.İstanbul Şehremaneti'nin Harp Kazançları Vergisi'nden Hisse Talebi}

İstanbul Şehremaneti'nin, içinde bulunulan harp şartlarından dolayı, masrafları artmış ve bütçesi açık vermişti. Bu nedenle bütçe açı̆̆ının kapatılabilmesi için Hükümet tarafından Şehremaneti'ne yardım yapılması istenmiştir. Bu konu ile ilgili olarak Şehremaneti tarafından farklı tarihlerde Dâhiliye Nezareti'ne üç defa tezkere gönderilmiştir (24, 29 Aralık 1919 ve 20 Ocak 1920) (BOA, DH. UMVM 162: 83, L.1-3). Bu tezkirelerde şu hususlara dikkat çekilmiştir: İstanbul Şehremaneti'nin bütçesi 1919 senesinde 1,5 milyon lira açık vermiş, 1920 senesinde de 1 milyon 700 bin lira açık vermesi beklenmektedir. Ancak bütçe açığının meydana gelmesinin muhtelif sebepleri vardı. Bunlardan birisi Şehremaneti'ne bağlı olarak çalışan hastanelerdi. Çünkü Osmanlı şehirlerinde belediye hastanelerinde o şehir halkından muhtaç bulunanlar ücretsiz tedavi ediliyordu. Buna bağlı olarak da muhtelif sebeplerden dolayı belediye hastanelerine sevk edilen hastaların tedavi ücretleri, hastaların mensup bulundukları şehir ve kasaba belediyelerince ödenmekte idi. İstanbul Şehremaneti'ne bağlı hastanelerde de senede 550'e yakın hasta tedavi edilmekte idi. Ancak tedavi edilen bu hastalardan \% 10'nu, yani 55 kişi, İstanbul ahalisindendi. Geri kalanı olan \% 90'nı yani 495 kişi diğer şehirlerden gelen insanlardı. Ancak bu hastalar için ilgili belediyelerden tedavi ücreti alınamıyordu. Bunun yanında İstanbul Şehremaneti tarafından hekim, memur ve hademelere verilen ücret ile sair masraflar için yıllık 400 bin lira sarf ediliyordu. Yalnız genel kaidelere aykırı olarak bu paranın \% 90'nı olan 360 bin lira taşra ahalisi namına sarf ediliyordu. Bu masrafların yanında Şehremaneti bütçesinin açık vermesinin sebepleri arasında temizlik ve aydınlatma giderleri de bulunuyordu. İstanbul Şehremaneti temizlik işleri için yıllık 780 bin lira saf ediyordu. Bu bedele Şehremaneti'nin aydınlatma giderleri de eklendiği zaman toplam 1,5 milyon liradan fazla bir masraf ortaya çıkıyordu. Bunun yanında İstanbul Şehremaneti, asli görevleri arasında bulunan temizlik işleri ile imar işlerini de gereği gibi yapamıyordu. Çünkü içinde bulunulan harp şartlarından dolayı amele tedarikinde güçlük çekiliyordu. Ayrıca inşaat malzemesi fiyatları artmıştı. İstanbul Şehremaneti, emanette görev yapan memur ve hizmetlilerin maaşını da veremiyordu (BOA, DH. UMVM. 162: 83, L.1-3).

Bu nedenlerden dolayı, İstanbul Şehremaneti tarafından 20 Ocak 1920 tarihinde Dâhiliye Nezareti'ne gönderilen tezkerede şu hususlar yer almıştır. Şehremaneti kendisine bağlı olan tebahhurhane ${ }^{4}$ ile hastanelerin Sihhiye Genel Müdürlüğü'ne devir edilmesini ve bu durum gerçekleştiği takdirde buralarda yardıma muhtaç olan hastaların tedavi edilmesi halinde, ücretlerinin Şehremaneti tarafından ödeneceği ifade etmiştir. Ancak hastanelerin Şehremaneti'nden ayrılmaması halinde burada tedavi edilen hastalardan \% 90'ın masrafının Hükümetçe tediye edilmesini istemiştir. Ayrıca İstanbul halkından tahsil edilmekte olan Temettu Vergisi'nin tamamının, Harp Kazançları Vergisi'nin 1/4'nün, Müsakkafat Vergisi'nin ${ }^{5}$ en son olarak arttırılan ve hükümetçe tahsil edilen miktarının 1/3'nün, petrol, şeker ve sairden alınan İstihlak Vergisi'nin yarısının Şehremaneti'ne bırakılmasını talep etmiştir (BOA, DH. UMVM. 162: 83, L.1- Bu talepler karşısında, gerektiği için bazı vergilere zam yapıldığı, buna rağmen vergilerin tahsil edilmesinde müşkülat çekildiği tespitinde bulunan Maliye Nezareti; İstanbul Şehremaneti'ne ait hisselerin de aynı miktarda arttırılması halinde, vergilerin tahsil edilmesinin bir kat daha sıkıntıya gireceği ve daha sonra da bu vergilerin tahsil edilemeyeceği görüşündeydi. Buna rağmen Maliye Nezareti, Şehremaneti'nin bütçe açı̆̆ının en aza indirilmesi

4 Hastalara buğu yapılan yer. (Devellioğlu 1998: 1045).

5 Bina Vergisi (Eldem 1994: 194). 
gerektiğine de inanıyordu. Bu nedenle Şehremaneti'nin hisselerinin iki misline çıkarılmasına olumlu bakıyordu. Ancak Temettu Vergisi ile Harp Kazançları Vergisi ve İstihlak Vergisi'nin bir kısmının Şehremaneti'ne terk edilmesini uygun görmüyordu. Çünkü adı geçen vergiler, doğrudan doğruya her mahalde genel bütçeye dâhil olan vergilerdendi. Bunun için Maliye Nezareti tarafından bu vergilerin kısmen veya tamamen Şehremaneti'ne bırakılması için bir sebep görülmüyordu. Bunun yanında Maliye Nezareti, Şehremaneti'nin yönetimi altında bulunan adı geçen hastaneler ile bu kurumlarda görev yapan doktorların da, İstanbul halkının istifadesine tahsis olunduğu tespitini yapmıştır. Bu nedenden dolayı, bunlarla ilgili her türlü masrafın İstanbul Şehremaneti bütçesinden karşılanması gerektiği görüşündeydi. Ancak Hükümetçe tedavileri uygun görülen kimseler olduğu takdirde, bunlara yapılan masraflar için, Şehremaneti'ne Hazine tarafından yardım yapılmasının uygun olacağını, ancak şehrin fakirleri arasına alınarak Şehremaneti tarafından tedavileri yapılan sair vilayet halkı için yardım yapılmasına imkân bulunmadığı tespitini yapmıştır. Bununla birlikte Maliye Nezareti'nce, Şehremaneti tarafından, bu gibi hastaların tedavi giderlerinin tahsil edilebilmesi için, bu hastaların mensup oldukları mahaller belediyelerine başvurulması gerektiği görüşündeydi ( BOA, DH. UMVM. 162: 83, L.4 ).

Maliye Nezareti bu tespit ve görüşlerinden başka bir tedbir bulunmadığını Dâhiliye Nezareti'ne bildirmiştir. Ayrıca konu ile ilgili olarak 25 Nisan 1920 tarihinde Sadaret'e bilgi vermiştir ( BOA, DH. UMVM. 162: 83, L.5 ).

\subsection{Bütçe Gelirlerinde Harp Kazançları Vergisi Miktarı}

Harp Kazançları Vergisi Hakkında Kararname yayınlandıktan sonra, merkezi hükümet tarafından, adı geçen verginin tahsil edilmesi konusunda bazı çalışmalar başlatılmıştı. Mesela; İstanbul Defterdarlığı'nın talebi üzerine Maliye Nezareti tarafından Dâhiliye Nezareti'nden 16/17 Şubat 1920 tarihinde Harp Kazançları Vergisi'nin tarhına esas olmak üzere, adı geçen kararnamenin 16. Maddesi gereğince gerek sözleşme ile müteahhit sıfatıyla, gerek her zamanki gibi pazarlıkla her nevi eşya, erzak ve benzeri satanların isimleri ile satılan malın bedelinin gösterildiği defterler talep edilmiştir. Fakat bu defterlerin Dâhiliye Nezareti tarafından Maliye Nezareti'ne gönderilmediği görülmüştür. Bunun üzerine Maliye Nezareti'nce 19 Nisan 1920 tarihinde Dâhiliye Nezareti'nden adı geçen defterler tekrar talep edilmiştir (BOA, DH. EUM. MH. 206: 102).

Yine İstanbul Defterdarlığı tarafından 13 Ocak 1920'de Şûrâ-yı Devlet'e bir tezkire gönderilmiştir. Bu tezkirede; Harp Kazançları Vergisi Kararnamesi'nin 4. Faslının 16. Maddesi'nin 1. Fıkrası'na uygun olarak Şûrâ-yı Devlet'e bağlı olan daire, şube ve kurumlara gerek sözleşme ile müteahhit sıfatıyla ve gerek her zamanki gibi pazarlık suretiyle her nevi eşya, erzak ve emtia satan veya nakliyat, inşaat ve imalat icra eden müteahhitlerden sözleşme gereğince 1916 senesi Ocak ayından 1918 senesi Aralık ayı sonuna kadar istifa ettikleri meblağların beher seneye ait yekûnlarının ayrı ayrı ve pazarlıkla mal satanların da her defada tahakkuk eden istihkakları miktarını açıklayan, ayrıca bu kişilerin isim ve mahalli ikametlerinin de yer aldığı bir defterin tanzim edilmesi ve müddeti içerisinde gönderilmesi istenmiştir (BOA, ŞD. 2387: 20, L.1).

Ancak Şûrâ-yı Devlet'e bağlı olan daireler için gerek ihale ve gerek pazarlık sureti ile büyük miktarda satın alma meydana gelmiyordu. Bununla birlikte aydınlatma, 1sıtma ve müteferrik masraflar için harcama yapılıyordu. Bu harcamalar da Dâhiliye Nezareti ile birlikte tedarik ve sarf olunuyordu. Perakende satın alma talep edildiği takdirde, bu da esnaf veya tüccardan 
yapılıyordu. Bu satın almalar karşılı̆̆ı alınmış olan senetler de Dâhiliye Nezareti'nin muhasebesine veriliyordu. Bu nedenle Şûrâ-yı Devlet tarafından 21 Ocak 1920'de İstanbul Vilayeti Defterdarlığı'na gönderilen yazıda, kendilerinde talep edilen konu ile ilgili olarak bir kayıt ve malumat olmadığı bildirilmiştir (BOA, ŞD. 2387: 20, L.2).

$\mathrm{Bu}$ arada bazı vergi mükellefleri, Harp Kazançları Vergisi Kararnamesi'ne göre, kendilerine tahakkuk eden vergilerini ödemişlerdi. Ancak adı geçen kararnamenin uygulanmasının, 1920 yılı Bütçe Kanunu ile ertelenmesi üzerine, Harp Kazançları Vergisi'ni ödeyen mükellefler, yatırmış oldukları vergi bedellerinin kendilerine iade edilmesini Maliye Nezareti'nden talep etmişlerdi. Bu talepler üzerine Maliye Nezareti 14 Haziran 1921 tarihinde Meclis-i Vükela'ya göndermiş olduğu yazıda, bu konuda ne yapılması gerektiği hakkında görüş sormuştur. Meclis-i Vükela tarafından 23 Haziran 1921 tarihinde yapılan toplantıda, bu konu görüşülmüş̧ür. Burada yapılan görüşmede:

Adı geçen bütçe kanunu ile Harp Kazançları Vergisi'nin ortadan kaldırılmadığı, ancak tahakkuk ettirilecek olan vergilerin tahsil edilmesinin tecil edildiği, bu durum karşısında da yatırılan vergi bedellerinin mükelleflere iade edilmesi gerektiği tespit edilmiştir. Bu sebeple yapılan uygulama geçerliliğini yitirmiş olduğu için, tahsil edilen miktarların mükelleflere iade edilmesi gerektiğine karar verilmiştir" (BOA, MV. 221: 188).

Görüldüğü gibi ülkenin içinde bulunduğu siyasi ve askeri buhranlardan dolayı merkezi hükümet, Harp Kazançları Vergisi'nin tahsil edilmesi konusunda sağlıklı bir çalışma yapamamıştır. Bu arada, adı geçen verginin tahsil edilmesi Ankara Hükümeti'nin de gündemine gelmiştir. Böylece Türkiye Büyük Millet Meclisi'nin 25 Ekim 1920 tarihli kanunu kabul etmesiyle Harp Kazançları Vergisi'nin tahsilâtı yolunda ilk çalışma gerçekleştirilmiştir. Daha sonra çıkarılan kanunlarla da adı geçen verginin tahsilâtına başlanmıştır. İlk defa devletin 1922 yılı Gelirler Bütçesi'nde bu gelir faslı gösterilmiştir. Harp Kazançları Vergisi'nin Dolaysız Gelir Vergileri içindeki oranı 1922'de \% 2.06 (Duru-Turan vd. 1982: 1/314), 1923'de \% 2.48 (Duru-Turan vd. 1982: 1/372), 1924'de \% 3.41 (Türkiye Büyük Millet Meclisi Zabıt Ceridesi 1970: 7/44) ve 1925 yılında da \% 1.87 olmuştur (Türkiye Büyük Millet Meclisi Zabıt Ceridesi 1976: 18/150).

1922-1925 yılları arasında Harp Kazançları Vergisi'nin Dolaysız Gelir Vergileri içindeki oranı \% 2.51'dir. Bu dört yıllık sürede toplam tahsilât miktarı da 3.850 .000 lira olarak hesaplanmıştır. (Türkiye Büyük Millet Meclisi Zabıt Ceridesi 1970: 7/44; Türkiye Büyük Millet Meclisi Zabit Ceridesi 1976: 18/150; Duru-Turan vd. 1982: 1/314, 372).

1926 yılından itibaren devletin Gelirler Bütçesi'nde, Temettu ve Harp Kazançları Vergisi'ne yer verilmemiştir. Çünkü adı geçen yıldan itibaren Temettu Vergisi kaldırılmış, yerini de Kazanç Vergisi almıştır (Resmi Gazete 1926: 321/1145).

Tablo 1: Dolaysız Vergiler içinde Harp Kazançları Vergisinin Yeri. 


\begin{tabular}{|l|l|l|l|l|}
\hline Y1llar & Dolaysız Vergiler & $\begin{array}{l}\text { Temettu ve Harp } \\
\text { Kazançları Vergisi }\end{array}$ & Harp Kazançları Vergisi & $\begin{array}{l}\text { Oran } \\
\%\end{array}$ \\
\hline 1922 & 29.062 .000 & 1.800 .000 & 600.000 & 2.06 \\
\hline 1923 & 40.319 .000 & 3.500 .000 & 1.000 .000 & 2.48 \\
\hline 1924 & 43.930 .500 & 4.000 .000 & 1.500 .000 & 3.41 \\
\hline 1925 & 39.930 .500 & 4.250 .000 & 750.000 & 1.87 \\
\hline Toplam & 153.242 .000 & 13.550 .000 & 3.850 .000 & 2.51 \\
\hline
\end{tabular}

(Türkiye Büyük Millet Meclisi Zabıt Ceridesi 1970: 7/44; Türkiye Büyük Millet Meclisi Zabıt Ceridesi 1976: 18/150; Duru-Turan vd. 1982: 1/314, 372.)

\section{Harp Kazançları Vergisi'nin Tecil Edilmesi ve Alınmaması}

Vergi mükellefi olan gerçek ve tüzel kişilerden bazıları Harp Kazançları Vergisi ile mükellef tutulmamak için, devletin çeşitli organlarından muhtelif talepler de bulunmuşlardır. Bu talepler arasında Harp Kazançları Vergisinin Temin-i tahsili İçin Tedabir-i evveliyeyi muhtevi kanun ve Harp Kazançları Vergisi Kararnamesi'nin kapsamı dışına çıkarılmak veya bu kanunlardan muaf olmak yanında, adlarına tahakkuk eden Harp Kazançları Vergisi'nin geciktirilmesi veya tahsil edilmemesi gibi hususlar bulunmaktadır. Bu talepler merkezi hükümet döneminde Maliye ve Dâhiliye Nezaretleri ile Şûrâ-yı Devlet'e, Milli Mücadele ve Cumhuriyet döneminde de, Maliye Vekâleti'ne ve Türkiye Büyük Millet Meclisi'ne gönderilmiş ve bu kurumlar tarafından çözüme kavuşturulması istenmiştir. Mesela; Harp Kazançları Vergisi kapsamı dışında tutulmakla ilgili taleplerden birisi, Aydın İncir Müstahsilleri Kooperatifi Anonim Şirketi Müdürlüğü'nce yapılmıştır. Çünkü adı geçen şirket tarafından; Aydın İncir Müstahsilleri Anonim Şirketi'nin, şirketin hissedarları tarafından nakden vuku bulan mevduat üzerine teşekkül eden ve muamele neticesinde sermayeye temettu ayıran şirketlerden birisi olmadığ 1 iddia edilmiştir. Bunun yanında bu şirketin ortaklarının malını teslim ile nakde çeviren ve başlangıçta teslim edilen mal mukabilinde tahmini ve itibari ita ettiği avansı meydana gelen giderlere ekleyerek, geri kalan bedeli, mal bedeli olarak tamamen ortaklarına tevzi eden bir satış kooperatifi olduğu ileri sürülmüştür (BOA, ŞD. 3154: 46, L.1).

$\mathrm{Bu}$ gerekçeler ile bahse konu şirket tarafından Maliye Nezareti'ne gönderilen dilekçede, Harp Kazançları Vergisi'nin Temin-i tahsili İçin Tedabir-i evveliyeyi muhtevi kanun hükümlerinin, adı geçen şirkete teşmil olamayacağ 1 ifade edilmiştir. Ancak bu kanunun 1 . Maddesi'nde; Osmanlı ülkesi dâhilinde faaliyet gösteren bilumum anonim şirketlerle anonim şeklinde olan kooperatif ve sermayeleri senetlere bölünmüş komandit şirketlerin kârlarını tevzi edecekleri sırada özel bir ihtiyat akçesi teşkil etmeğe mecbur bulundukları hüküm altına alınmıştı. Bu nedenle Maliye Nezareti tarafından 12 Temmuz 1918 tarihinde Sadaret'e gönderilen tezkerede;

Aydın İncir Müstahsilleri Anonim Şirketi'nin özel bir vaziyete sahip olduğu ifade edilmiş, ancak Harp Kazançları Vergisi'nin Temin-i tahsili İçin Tedabir-i evveliyeyi muhtevi kanunun açık hükmüne nazaran, adı geçen şirketin kanunun kapsamı haricinde tutulmasının mümkün olamayacağı gerekçesi ile konunun, Şûrâ-yı Devlet tarafından tetkik edilmesi talep edilmiştir" (BOA, ŞD. 3154: 46, L.1).

Maliye Nezareti'nin bu talebi 28 Temmuz 1918 tarihinde Şûrâ-yı Devlet Maliye ve Nafia Dairesi'nde görüşülmüştür. Burada yapılan görüşmede konu ile ilgili olarak şu karar alınmıştır:

Harp Kazançları Vergisi'nin Temin-i tahsili İçin Tedabir-i evveliyeyi ihtiva eden 4 
Nisan 1918 tarihli Kanun'un kapsamına dâhil olan şirketler ile bunların mükellefiyet suretinden bahseden 1. Maddesi'nin ilk kısmındaki Osmanlı ülkesi dâhilinde faaliyet gösteren bilumum anonim şirketler fıkrası, her ne mahiyet ve şekilde olursa olsun anonim nam ve unvanı altında kurulmuş olan bilcümle şirketleri kanunun tatbik sahasına almaktadır. Bunun yanında anonim şeklinde olan kooperatif şirketler suretinde yazılmış olan ikinci fıkrasında da, bu yolda kurulmuş olan kooperatif şirketler kanunun hükmüne tabi kılınmıştır. Bu nedenle Aydın İncir Müstahsilleri Kooperatifi Anonim Şirketi her iki bakış açısında da adı geçen kanunun hüküm sahası içine girmektedir (BOA, ŞD. 3154: 46, L.2-3).

Şûrâ-yı Devlet Maliye ve Nafia Dairesi'nin almış olduğu bu karar, Şûrâ-yı Devlet Genel Kurulu tarafından 28 Ekim 1918 tarihinde görüşülmüştür. Burada yapılan görüşme sonunda; Aydın İncir Müstahsilleri Kooperatifi Anonim Şirketi'nin, anonim şirket halinde olmayıp, anonim şeklinde kooperatif bir şirket olduğuna ve bu nevi şirketlerin Harp Kazançları Vergisi'nin Temin-i tahsili İçin Tedabirleri ihtiva eden kanunun kapsamı içine gireceğine dair, adı geçen daire tarafından alınmış olan karar, ek bir kararla tasdik edilmiştir. Bununla birlikte Şûrâ-yi Devlet Maliye ve Nafia Dairesi tarafından kabul edilen kararın, Maliye Nezareti'ne de bildirilmesi istenmiştir (BOA, ŞD. 3154: 46, L.4).

Bunun üzerine Aydın İncir Müstahsilleri Kooperatifi Anonim Şirketi İdare Meclisi Reis Vekili Mehmet Nazmi Bey tarafından 29 Ağustos 1918 tarihinde Şûrâ-yı Devlet Başkanlığı'na bir dilekçe verilmiştir. Bu dilekçede, ilk önce adı geçen kooperatifin teşekkül etmesi, kuruluş gayesi, çalışma şekli ve anonim şirketlerden farkı üzerinde durularak, kooperatiften Harp Kazançları Vergisi'nin tahsil edilmesi halinde, öşür resmine tabi olan mükelleflerden, ikinci bir vergi alınmış olacağı tespiti yapılmıştır. Daha sonra da, bahse konu kooperatifin Harp Kazançları Vergisi'nin Temin-i tahsili İçin Tedabir-i evveliyeyi muhtevi kanununun kapsamı dışına çıarılması talep edilmiştir (BOA, ŞD. 3154: 46, L.5).

Adı geçen dilekçe, 29 Temmuz 1919 tarihinde Şûrâ-yı Devlet Maliye ve Nafia Dairesi'nde görüşülmüştür. Burada yapılan görüşmede; dilekçe sahibi tarafından iddia edilen hususların yeni delilleri kapsamadığı, bunların bilinen iddiaların tekrarından ibaret olduğu ve bu nedenle eski kararın değiştirilmesine gerek olmadığı ifade edilerek, adı geçen dilekçenin Şûrâ-yı Devlet Genel Kurulu'na gönderilmesine karar verilmiştir (BOA, ŞD. 3154: 46, L.6).

Şûrâ-yı Devlet Genel Kurulu da 25 Eylül 1919 tarihinde yaptığı toplantıda, Maliye ve Nafia Dairesi'nin kararını uygun bulmuş ve bu kararla birlikte, Aydın İncir Müstahsilleri Kooperatifi Anonim Şirketi İdare Meclisi Reis Vekili Mehmet Nazmi Bey'in dilekçesinin Ticaret ve Ziraat Nezareti'ne gönderilmesini talep etmiştir (BOA, ŞD. 3154: 46, L.7).

Konu hakkında Şûrâ-yı Devlet tarafından, 1 Kasım 1919 tarihinde Ticaret ve Ziraat Nezareti'ne gerekli tebliğ yapılmıştır (BOA, ŞD. 3154: 46, L. 8).

Ticaret ve Ziraat Nezareti de gerekli işlemin yapılması için, Şûrâ-yı Devlet tarafından gönderilen Maliye ve Nafia Dairesi kararını ve Aydın İncir Müstahsilleri Kooperatifi Anonim Şirketi İdare Meclisi Reis Vekili Mehmet Nazmi Bey'in dilekçesini, Ticaret Genel Müdürlüğü'ne havale etmiştir. Yalnız Ticaret Genel Müdürlüğü de, adı geçen dilekçedeki iddiaları yerinde bulmakta ve bilhassa kooperatifçiliğin gelişmesinin Osmanlı ülkesi için önemi üzerinde durarak, Mehmet Nazmi Bey'in talebinin Şûrâ-yı Devlet tarafından karara bağlanmasını istemekteydi. Bunun üzerine Ticaret ve Ziraat Nezareti, Ticaret Genel Müdürlügüu'nün ortaya koyduğu olumlu görüş ve tespitleri içeren bir tezkereyi, 10 Ocak 1920 tarihinde Şûrâ-yı Devlet'e göndererek, konu hakkında gerekli işlemin yapılmasını istemiştir (BOA, ŞD. 3154: 46, L.9).

Ancak, Ticaret Genel Müdürlügü̈nün Aydın İncir Müstahsilleri Kooperatifi Anonim Şirketi 
hakkındaki olumlu görüş ve tespitleri Şûrâ-yı Devlet tarafından dikkate alınmamıştı. Çünkü Şûrâ-yi Devlet, adı geçen tezkerenin muhtevasının, önceki iddiaların tekrarından başka bir şey olmadığı kanaatini taşıyordu. Bu nedenle, Maliye ve Nafia Dairesi'nin almış olduğu kararın değişmesi için bir sebep olmadığı tespitini yaparak, dilekçe sahibine bu doğrultuda bilgi verilmesine karar vermiştir (26 Mart 1920) (BOA, ŞD. 3154: 46, L.10).

Böylece Aydın İncir Müstahsilleri Kooperatifi Anonim Şirketi'nin çözülmesini istediği bir mesele, Maliye ile Ticaret ve Ziraat Nezaretleri'nin konuya olumlu yaklaşmasına rağmen, Şûrâyı Devlet'in meseleye sadece kanun tekniği açısından bakmasından dolayı olumlu neticelenmemiştir. Bu bakış açısını da, ülkede yeni teşekkül etmekte olan bir kuruluşun yöneticileri ve ortaklarının iyi niyetli çalışmalarına engel çıkarmak olarak kabul etmek gerekir.

Bunun yanında Harp Kazançları Vergisi'nden muaf tutulma konusunu içeren bir başvuru da Adana Valiliği'nden Dâhiliye Nezareti'ne yapılmıştır. Şöyle ki; Fabrikatör Simon oğlu Serkas ve iki arkadaşı tarafından 31 Mart 1920 tarihinde Adana Valiliği'ne iki dilekçe verilmiştir. Bu dilekçelerde, Adana Vergi Şubesi tarafından 23 Mart 1920 tarihinde Harp Kazançları Vergisi hakkında kendilerine bir ihtarname tebliğ edildiği, ancak yürürlüğe girmemiş olan Harp Kazançları Vergisi Hakkındaki Kanun Tasarısı'nda, fabrikaların Harp Kazançları Vergisi'ne tabii tutulacağına dair bir kayıt ve işaret olmadığı ifade edilmiştir. Daha sonra da Teşvik-i Sanayi Kanunu'nun ${ }^{6}$ fabrikalara bahşettiği muafiyetten istifade eden fabrikaların, bu vergiye tabii olamayacağından dolayı gerekli işlemin yapılması istenmiştir. Bu nedenle Adana Valiliği tarafından 6 Nisan 1920 tarihinde Dâhiliye Nezareti'ne gönderilen yazıda da bu hususlara dikkat çekilmiştir. Ayrıca bu fabrikaların harpten evvel Adana'da tesis edilmiş olduğu, bunlardan başka vilayet dâhilinde daha birçok fabrikanın bulunduğu, Harp Kazançları Vergisi Hakkındaki Kanun'da da, bu fabrikaların adı geçen vergi ile mükellefiyetlerine dair bir fıkra mevcut olmadığı bildirilerek, bu konuda gereli işlemin yapılması istenmiştir (BOA, DH. İ. UM. 3: 1, L.1).

Dâhiliye Nezareti de, fabrika sahiplerin göndermiş olduğu dilekçeler ile Adana Valiliği'nin bu konudaki görüşü hakkında, 21 Nisan 1920 tarihinde Maliye Nezareti'ne bilgi vermiştir. Ayrıca bu konu hakkında yapılması gereken işlemin tespit edilerek bildirilmesini talep etmiştir (BOA, DH. İ. UM. 3: 1, L.2).

Bunun üzerine Maliye Nezareti tarafından 2 Mayıs 1920 tarihinde Adana Vilayeti'ne gönderilen cevabi yazıda şöyle denmektedir.

Harp Kazançları Vergisi Kararnamesi'nin muafiyet faslında zikir ve tadat edilen temettu sahipleri arasına Teşvik-i Sanayi Kanunu gereğince Temettu Vergisi'nden muaf olan fabrika sahipleri dâhil edilmemiştir. Ayrıca vergiye tabii muhtelif mükelleflerin kanunlarda belirtilmesine ve sayılmasına yer verilmemesinden dolayı, muafiyet faslına dâhil olmayan mükelleflerden kararname gereği Harp Kazançları Vergisi'nin tarhı lazım gelmektedir ( BOA, DH. İ. UM. 3: 1, L.3).

Maliye Nezareti aynı tarihte konu ile ilgili olarak Dâhiliye Nezareti'ne de bilgi vermiştir. Buna bağlı olarak Dâhiliye Nezareti de 3 Mayıs 1920 tarihinde Adana Vilayeti'ni konu hakkında haberdar etmiştir (BOA, DH. İ. UM. 3: 1, L.4).

Tahakkuk edilen Harp Kazançları Vergisi'ne bir itiraz da Maraş (Kahramanmaraş)'tan gelmiştir. Mondros Mütarekesi'nden (30 Ekim 1918) sonra Maraş, ilkönce İngilizler (22 Şubat 1919)7 daha sonra da Fransızlar tarafından işgal edilmişti (30 Ekim 1919) ${ }^{8}$. İşgal sırasında Maraş

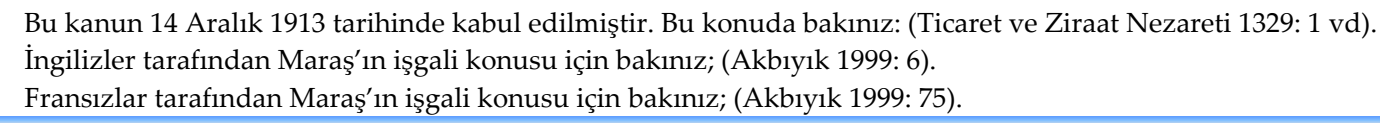


çarşı ve pazarı Fransızlar ve Ermeniler tarafından istila edilerek, dükkân ve mağazalardaki ticari mülk ve eşyalar ile tüccara ait bütün kasalar tahrip ve yağma edilmişti. Bu nedenle mahalli halk tarafından Harp Kazançları Vergisi'nden muaf tutulmaları Maliye Vekâleti'nden talep edilmişti. Çünkü Harp Kazançları Vergisi'nin 2. Maddesi'nin 11. Fıkrası'nda; son harpte düşman tarafından işgal edilen mahallerden hicret edenler ile genel olarak başka yerlere nakil ve hicret edilenlerin Harp Kazançları Vergisi'nden muaf olması hüküm altına alınmıştı. Bu nedenle İngiliz ve Fransızlar tarafından Maraş'ın işgal edilmesi sebebi ile burada yaşayan halkın zarar ve musibete uğramış olduğu tespitini yapan Maliye Vekâleti, bu gibi kişilerin, adı geçen kanun maddesinin bahsettiği muafiyetten faydalanmasını uygun görmüştür. Ancak, adı geçen vekâlet tarafından, halk arasında zarara uğramayan tüccarların bu muafiyetten istifade etmelerini uygun görmeyerek, bu gibilere kanun hükmünün tatbik edilmesi mahalline bildirilmiştir. Buna rağmen Maraş Bidayet Tarh Komisyonu'nun hazırlayarak, Maliye Vekâleti'ne gönderdiği mazbatada, livada zarar görmedik hiçbir kişinin kalmadığı beyan edilerek, kanunun vermiş olduğu muafiyetin bütün halka teşmil edilmesi gerektiği üzerinde durulmuştur (BCA, BKK, 030.18.01: 01.5.33, L.1).

Bunun üzerine Maliye Vekâleti tarafından 22/23 Eylül 1921 tarihinde Başvekâlet'e gönderilen tezkirede; Adı geçen kanun hükmünde bahsedilen muafiyetin Umumi Harp'te hicret edenlerle tehcir edilenleri kapsadığı, düşmandan istirdat olunan mahallerin Emlak, Arazi, Temettu ve Aşar Vergileri'nin 1917 senesi nihayetine kadar olan bakayasının affını içeren 31 Ekim 1921 tarihli Kanunun, Harp Kazançları Vergisi'nden muafiyeti de ihtiva ettiği tespit edilmiştir. Bununla birlikte Maraş ahalisinin istila dolayısıyla zarar görmüş oldukları belli ise de hicret vaki olmadığından, adı geçen liva dâhilinde harp seneleri içindeki kazançlardan kararname dairesinde vergi alınmasının lazım gelip gelmeyeceği hususunun tefsir edilmesi talep edilmiştir (BCA, BKK, 030.18.01: 05.33.11, L.1).

Bunun üzerine İcra Vekilleri Heyeti tarafından 24 Kasım 1922 tarihinde yapılan toplantıda Maliye Vekâleti'nin talebinin, Türkiye Büyük Millet Meclisi'ne gönderilmesine karar verilmiştir (BCA, BKK, 030.18.01: 01.5.33, L.1).

Harp Kazançları Vergisi'nin tahsil edilmesi konusunda bir itiraz da Denizli'den yapılmıştır. Denizli Livası'na bağlı Sarayköy Kazası'nın Kadıköy Nahiyesi halkından Zeybek oğlu Necip ve dört arkadaşı tarafından Türkiye Büyük Millet Meclisi Başkanlığı'na tarh edilmiş olan Harp Kazançları Vergisi'ne itirazı konu alan bir dilekçe gönderilmiştir. 11 Nisan 1923 tarihinde Maliye Vekâleti tarafından bu dilekçeye verilen cevap, Denizli Mutasarrıflı̆̆ 1 tarafından 30 Nisan 1923 tarihinde, dilekçe sahibi kişilere iletilmiştir. Maliye Vekâleti'nin cevabında; adı geçen kişilerin mükellef tutuldukları Temettu Vergisi'nin üç veya altışar misli maktu vergi ile mükellefiyetlerine ve matrah vergilerinin de bu surette olacağına karar verildiği bildirilmiştir. Ayrıca bu karardan istifade etmeleri lüzumu anlatılarak, matrah vergilerinin ödenmemesi halinde mallarının haczedileceği ifade edilmiştir. Bunun üzerine bahse konu kişiler 3 Eylül 1923 tarihinde Denizli Livası mebuslarına bir telgraf çekerek konu hakkında bilgi vermişlerdir. Denizli Mebusu Yusuf, Necip Ali ve Haydar Rüşdi Beyler tarafından 3 Eylül 1923 tarihinde Türkiye Büyük Millet Meclisi Başkanlığı'na konu ile ilgili olarak bir takrir verilmiştir. Bu takrirde, Denizli Livası halkı ve bilhassa Sarayköy ve Kadıköy Nahiyesi'nin cephe olmalarından dolayı son derece zarar gördükleri, bu nedenle düşman istilasından kurtarılmış vilayetler gibi Harp Kazançları Vergisi'nden istisna edilmelerinin lazım geleceği tespiti yapılmıştır. Daha sonra da Kadıköy Nahiyesi ile Denizli Vaka-i Cinaiyesi'nde ${ }^{9}$ mevcut servetlerinin hepsi yağma ve tahrip edilen Denizli merkez kazası halkının Harp Kazançları Vergisi'nden istisnası ve

9 Denizli Vaka-i Cinaiyesi konusu için bakınız;( Köstüklü, 1999: 183 vd). 
tahsilâtın tehir edilmesi, ayrıca bu konu ile ilgili olarak Denizli yönetimine gerekli bilginin verilmesi talep edilmiştir (BCA, MUAMELAT, 030.10.00: 06.31.29, L.1).

Haydar Rüşdi Bey ve arkadaşları tarafından verilen bu takrir, Türkiye Büyük Millet Meclisi Tarafından 6 Eylül 1923 tarihinde İcra Vekilleri Heyeti'ne gönderilmiştir. Adı geçen heyet de gereğinin yapılması talebi ile bu takriri, 8 Eylül 1923 tarihinde Maliye Vekâleti'ne sevk etmiştir (BCA, MUAMELAT, 030.10.00: 06.31.29, L.2).

Maliye Vekâleti 11 Ekim 1923 tarihinde Başvekâlet'e gönderdiği tezkerede konu ile ilgili olarak şu cevabı vermiştir.

Denizli Livası merkez ve mülhakatı mükelleflerine ait Harp Kazançları Vergisi itiraz evrakı Merkez Temyiz Komisyonu'nca kanun hükümleri dairesinde tetkik edilmiştir. Mükelleflerin işgal dolayısıyla duçar oldukları zarar ve ziyanlar da dikkate alınarak, bunlardan harp senelerinde fevkalade gelir istihsal eyledikleri sabit olanlara, mahalli tarh komisyonlarınca matrah müterakki vergileri tasdik edilmiştir. Müterakki vergileriyle mükellefiyetleri icap edecek derecede fevkalade gelir istihsal edememiş olanların da, 1918 senesine ait Temettu Vergileri'nin üçer veya altışar misli derecesinde maktu vergiyle mükellefiyetlerine karar verilmiştir. Bu konuda alınmış olan karar, itiraz evraklarıyla beraber mahalline gönderilmiştir. Ancak bir müddet sonra Merkez Temyiz Komisyonu'nca ittihaz ve tebliğ olunan karar dikkate alınmayarak, başlangıçta tarh olunan vergilerin tahsiline teşebbüs edildiğinin haber alınması üzerine, Merkez Temyiz Komisyonu'nca ittihaz ve tebliğ olunan karar dairesinde muamele icrası mahalline tebliğ edilmiştir. Bunun yanında düşman istilasından kurtulan vilayetler ahalisinin Harp Kazançları Vergisi'nden istisna olmalarına dair bir kanun da mevcut değildir. Ancak işgal dolayısıyla zarar ve ziyana duçar olanlardan meydana gelen zararlarını, kanun dairesinde ispat edenlerin zarar ve ziyanlarının miktarı, verginin tarh edilmesi zamanında dikkate alınması kararlaştırılmış olduğundan gerek mülhakat, gerek Merkez Temyiz Komisyonu'nca bu yolda muamele ifa edilmektedir. Ayrıca her mahalde harp esnasında fevkalade gelir istihsal eyledikleri sabit olanların Harp Kazançları Vergisi'yle mükellefiyetleri bu konudaki kararname ahkâmından bulunmaktadır. Bunun yanında vuku bulan itirazlar üzerine Merkez Temyiz Komisyonu'nca gerekli tetkik yapılarak kesinleşmiş bulunan vergiden, adı geçen liva mükelleflerinin istisna edilmelerine dair bir kanun hükmü mevcut değildir (BCA, MUAMELAT 030.10.00: 06.31.29, L.3).

Başvekâlet, Maliye Vekâleti'nin gönderdiği bu tezkereyi, 11 Ekim 1923 tarihinde Türkiye Büyük Millet Meclisi'ne göndermiştir (BCA, MUAMELAT 030.10.00: 06.31.29, L.4).

Muhtelif şehirlerin yanında, hayır kurumları tarafından da tahakkuk eden Harp Kazançları Vergisi'nin tahsil edilmesine itiraz edilmiştir. Bu itirazlardan birisi Hilal-i Ahmer Cemiyeti tarafından yapılmıştır. Şöyle ki; İstanbul Vilayeti Harp Kazançları Vergisi Bidayet Tarh Komisyonu'nca Hilal-i Ahmer Cemiyeti namina mükellefiyet seneleri olan 1916, 1917 ve 1918 seneleri zarfında resmi dairelere ita eylediği erzak ve eşyadan dolayı 376 lira 490 kuruş Harp Kazançları Vergisi tarh ve tahakkuk ettirilmişti. Bunun üzerine adı geçen cemiyet tarafından İstanbul Defterdarlığı vasıtasıyla Maliye Vekâleti'ne bir itiraz evrakı gönderilmiştir. Bu konu hakkında Maliye Vekâleti 7 Aralık 1914 tarihinde Başvekâlet'e gönderdiği tezkerede şu talepte bulunmuştur:

“Harp Kazançları Vergisi Kararnamesi'nin 16. Maddesi'nde gerek muafiyete haiz olsun veya olmasın askeri cemiyetlere, çeşitli hükümet daire ve kurumlarına, gerek sözleşme ile müteahhit sıfatıyla, gerek adiyen pazarlıkla her nevi eşya, erzak ve emtia satanların istika eyledikleri mubayaa üzerinden Harp Kazançları Vergisi ödemekle mükellef oldukları ifade 
edilmişti. Ancak Harp Kazançları Vergisi Kararnamesi genel itibarıyla mükellefiyet seneleri olan üç harp senesinde, her ne suretle olursa olsun fevkalade gelir temin eden adi ve hükmi şahısların istihsal eylediği fevkalade gelirden vergi alınması maksadına matuftu. Hâlbuki Hilal-i Ahmer Cemiyeti yaptığı ticaretten elde ettiği hâsılatın anaparasını dahi özel maksadı olan hayır işlerine sarf ve tahsis etmekte ve bu gelirden maddi ve şahsi bir menfaat temin etmiyordu. Bunun için Hilal-i Ahmer Cemiyeti'nden Harp Kazançları Vergisi talep etmek, adı geçen cemiyet tarafından hayır işlerine tahsis edilen paradan vergi alınmasını gerektirecektir. Bu durumun Harp Kazançları Vergisi Kararnamesi'nin ruh ve maksadına uygun görülmediği ortadadır. Bunun için kanunun ilgili maddesinin tefsir edilmesini icap ettirmektedir" (BCA, MUAMELAT, 030.10.00: 135.968.05, L.1).

Maliye Vekâleti'nin bu talebi, Başvekâlet tarafından 10 Ocak 1924 tarihinde Türkiye Büyük Millet Meclisi Başkanlığı'na gönderilmiş ve bu konuda gerekli işlemin yapılması istenmiştir (BCA, MUAMELAT, 030.10.00: 135.968.05, L.1).

Maliye Vekâleti'nin bu talebi hakkında, Türkiye Büyük Millet Meclisi Kavanin-i Maliye Encümeni'nde alınan karar şu şekildedir:

Harp Kazançları Vergisiyle Hilal-i Ahmer Cemiyeti'nin dahi mükellef olup olamayacağına ait bu konudaki kanunun tefsirine dair Başvekâlet'in 6/122 numaralı ve 10 Ocak 1924 tarihli tezkiresi encümenimizce 22 Ocak 1924 tarihli toplantısında tetkik edildi. Harp Kazançları Kanunu'nun 12. Maddesi'nde umur ve hayır kurumlarına vuku bulan bağışlar ve yardımlar masraf kayıt edilmiş ise kabuldür diye yazılı olmasına ve bu gibi masrafların sair maddeler ahkâmına tevfikan fert ve şirketlerin gelirlerinden tenzil edilmekte bulunmasına nazaran Hilal-i Ahmer, bu gibi yardımları sermaye ittihaz etmek sureti ile bir kâr temin etse bile bütün masrafı, adı geçen maddedeki bağışlar kabilinden bulunmasına binaen Hilal-i Ahmer'in vergi ile mükellef tutulması kanun hükümlerinin ruh ve maksadıyla bağdaşır olamayacağına ekseriyetle karar verilmiş olmakla genel kurula takdim olunur (BCA, MUAMELAT 030.10.00: 135.968.05, L.2).

Kavanin-i Maliye Encümeni tarafından alınmış olan bu karar, Meclis Genel Kurulu'nun 10 Nisan 1924 tarihinde yapmış olduğu toplantıda kabul edilmiştir. Meclisçe kabul edilen karar, 12 Nisan 1924 tarihinde Türkiye Büyük Millet Meclisi Başkanlığı tarafından Başvekâlet'e gönderilmiştir (BCA, MUAMELAT, 030.10.00: 135.968.05, L.3). Başvekâlet de 14 Nisan 1924 tarihinde Türkiye Büyük Millet Meclisi tarafından kabul edilen karar hakkında Maliye Vekâleti'ne bilgi vermiştir (BCA, MUAMELAT, 030.10.00: 135.968.05, L.4).

Bunun yanında Musevi Cemaati'ne ait olan eytamhane için Harp Kazançları Vergisi talep edilmesi de itiraza konu olmuştur. Mükellefiyet seneleri zarfında 8.850 lira teferrug edilen eytamhaneden Harp Kazançları Vergisi Kararnamesi'nin 16. Maddesi'nin 8. Fıkrasına göre 12. Maddesi'nde yazılan müterakki nispet tarifesi üzerinden 1.270 lira Harp Kazançları Vergisi tarh ve tahakkuk ettirilmişti. Ancak eytamhanenin bir kısmı iane ve bir kısmı da vatandaşın parası ile yapılmıştı. Bunun yanında yapıldığı tarihte hahambaşı olan Hayim Naum Efendi tarafından eytamhanenin intikal işlemi gerçekleştirilmişti. Ayrıca öteden beri eytamhane olarak kullanılan bu binanın tahsis edilmiş bir geliri olmayıp, iane ve teberru ile idare ediliyordu. Bu gerekçeler ileri sürülerek, tarh ve tahakkuk ettirilmiş olan Harp Kazançları Vergisi'nin tahsil edilmemesi için, eytamhane Müdürü Anjel tarafından Maliye Vekâleti'ne kanuni süresi içinde bir itiraz dilekçesi verilmişti. Bununla birlikte Maliye Vekâleti de, adı geçen kararnamenin 18. Maddesinin 8. Fıkrasına göre bu verginin alınmaması gerektiği görüşünde idi. Ancak Harp Kazançları Vergisi Kararnamesi'nin muafiyet faslında, bu konuda bir açıklık bulunmadığından dolayı, Hazinece bir muafiyet tesisine imkân görülmüyordu. Bunun için Maliye Vekâleti, bu 
eytamhane başta olmak üzere, bütün hayır kurumlarının Harp Kazançları Vergisi'nden muaf tutulmaları için, Türkiye Büyük Millet Meclisi'nde bir karar alınmasının doğru olacağ görüşündeydi. Bu nedenden dolayı Maliye Vekâlet tarafından, konu hakkında 20 Ekim 1924 tarihinde Başvekâlet'e bir yazı gönderilerek, gerekli işlemin yapılması talep edilmiştir (BCA, MUAMELAT 030.10.00: 80.525.09, L.1). Başvekâlet de, Maliye Vekâleti'nin bu talebi hakkında Türkiye Büyük Millet Meclisi Başkanlığı'na bir tezkere göndermiştir (12 Ekim 1924) (BCA, MUAMELAT 030.10.00: 80.525.09, L.2).

Türkiye Büyük Millet Meclisi'nin 22 Mart 1926 tarihinde yapılmış olan toplantısında; ianeten ve teberru edilen para ile satın alınarak, şahsı namına teferrug edildiği halde, sonradan hayır kurumlarına terk ve tahsis edildiği sabit olan binalardan Harp Kazançları Vergisi alınmamasına dair bir karar alınmıştır. Bu karar hakkında Türkiye Büyük Millet Meclisi Başkanlığı tarafından 23 Mart 1926 tarihinde Başvekâlet'e bilgi vermiştir (BCA, MUAMELAT 030.10.00: 80.525.09, L.3). Başvekâlet de Türkiye Büyük Millet Meclisi tarafından alınan bu karar hakkında Maliye Vekâleti'ni bilgilendirmiştir (23 Mart 1926) (BCA, MUAMELAT 030.10.00: 80.525.09, L.4).

\subsection{Harp Kazançları Vergisi'nin Terkini}

Türkiye Büyük Millet Meclisi tarafından, 1930'lu yıllarda Harp Kazançları Vergisi'nden devlete borç bakiyesi kalmış mükelleflerin, bu borçlarının terkini hakkında hukuki bir çalışma yapılmıştır. Bunun neticesinde Meclis, 4 Haziran 1934 tarihli ve 2566 sayılı Vergi Bakayasının Tasfiyesine Dair Kanunu kabul etmiştir. Bu kanunla; Harp Kazançları Vergisi Kararnamesi'ne ve aynı konuda daha sonra çıkarılan kanunlara göre, Harp Kazançları Vergisi ile gecikme zamları vb. bakiyesinden, devlete borcu olan vergi mükelleflerinin, borçları terkin olunmuştur (Resmi Gazete 1934: 2750/4126).

Bununla birlikte Harp Kazançları Vergisi'nden dolayı devlete borcu olan ve İstanbul'da ikamet eden bir vatandaşın, bu borcu da terkin edilmiştir. Şöyle ki; İstanbul'un Beyoğlu Semti'nde bulunan Vapiyon Mağazası sahibi Dimitri Kurtoğlu'nun, İstanbul 2. Ticaret Mahkemesi tarafından iflasına karar verilmişti. Ancak adı geçen kişinin Harp Kazançları Vergisi'nden devlete 696 lira 6 kuruş borcu bulunuyordu. Bu alacağın tahsil edilmesi için ilkönce 1. daha sonra da 2. İflas Dairesi'ne dava açılmıştı. Bu arada İstanbul Adliye Binası'nda yangın çıkmıştı. Bunun üzerine dava yenilenerek 2.Ticaret Mahkemesi'ne sevk edilmişti. Ancak iflas evrak defterlerinin yandığ 1 ve bu nedenden dolayı adı geçen bu belgelerin 2 . Ticaret Mahkemesi ile adı geçen iflas dairelerinde bulunmadığı yapılan tetkik neticesinde anlaşılmıştı. Bu durumun ortaya çıkması üzerine, Maliye Vekâleti tarafından 21 Aralık 1938 tarihinde Başvekâlet'e gönderilen tezkirede; evrakı bulunmayan bu davanın takibine imkân kalmamış olduğundan, dava kaydının terkini zımnında ekli kararnamenin çıkarılması talep edilmiştir (BCA, MK 030.11.01: 127.48.15, L.1).

Maliye Vekâleti'nce konu ile ilgili hazırlanmış olan kararname, Başvekâlet tarafından 31 Aralık 1938 tarihinde Cumhurbaşkanlığı'na gönderilmiştir. Adı geçen kararname Cumhurbaşkanlığı tarafından aynı tarihte onaylanmıştır. Bu kararnameye göre Dimitri Kurtoğlu'nun Harp Kazançları Vergisi'nden devlete olan borcunun, terkin edilmesi uygun görülmüştür (BCA, MK 030.11.01: 127.48.15, L.2-3). Daha sonra Cumhurbaşkanlığı tarafından onaylanan kararname, Başvekâlet'e gönderilmiştir. Başvekâlet de konu hakkında Maliye Vekâleti'ni bilgilendirmiştir (BCA, MK 030.11.01: 127.48.15, L.4). 


\subsection{Yabancı Devlet Vatandaşlarından Harp Kazançları Vergisi Alınması}

Milli Mücadele döneminde yabancı devlet vatandaşlarının Harp Kazançları Vergisi'nden muaf olup, olmadıkları gündemi işgal etmiştir. Mesela: İran Sefareti tarafından 24 Şubat 1920 tarihinde Bab-1 Ali Hukuk Müşavirliği'ne gönderilen takrirde; İran Tebaası'ndan Harp Kazançları Vergisi alınmaması talep edilmiştir. Bunun üzerine konu Maliye Nezareti'ne intikal ettirilmiştir. Maliye Nezareti de 14 Mart 1920 tarihinde Bab-1 Ali Hukuk Müşavirliği'ne gönderdiği tezkerede şu hususlara dikkat çekmiştir;

İran Vatandaşları eski antlaşmaların geçerli olduğu dönemlerde bile, Memalik-i Osmaniye'de vergiler hakkındaki muafiyetten istifade etmemiştir. Devletler Genel Hukuku da, vergi yönünden İran vatandaşlarını Osmanlı vatandaşı yerine koymaktadır. Bu nedenle 14 Aralık 1919 tarihli Harp Kazançları Vergisi Kararnamesi ile ihdas olunan Harp Kazançları Vergisi'ni ödemeye mecburdurlar. Bununla beraber bazı sebeplerden dolayı, verginin tahsil edilmesi bilahare başlanılmak üzere tehir edilmiştir. Bu durumun İran tebaasına da teşmil edilmesinde hiçbir mani bulunmamaktadır (BOA, HR. HMŞ. İŞO 204: 41).

Ayrıca konu hakkında Bab-1 Ali Hukuk Müşavirliği tarafından 10 Nisan 1920 tarihinde İran Sefareti'ne bilgi verilmiştir (BOA, HR. HMŞ. İşO 204: 41).

Müttefik devletler hariç olmak üzere, yabancı devletlerin vatandaşlarından Harp Kazançları Vergisi alınıp, alınmaması tartışması Cumhuriyetin ilk yıllarında da devam etmiştir. Bu konu ile ilgili örneklerden birisi şudur. Maliye Vekâleti tarafından 31 Ocak 1925 tarihinde Başvekâlet'e gönderilen yazıda; Müttefik devletler hariç olmak üzere, başka devletlere ait vatandaşların Harp Kazançları Vergisi'nden istisna tutulmalarının icap edip etmeyeceği hakkında Vekiller Heyeti'nce bir karar alınması talep edilmiştir (BCA, MUAMELAT 030.10.00: 136.974.08, L.1).

Bu talep üzerine Başvekâlet tarafından Hariciye Vekâleti'ne, müttefik devletler hariç olmak üzere diğer devletler vatandaşlarının Harp Kazançları Vergisi'nden istisna edilip, edilmeyeceğinin tayin edilmesi hakkında görüş sorulmuştur. Hariciye Vekâleti de bu soru üzerine Başvekâlet'e verdiği cevapta; bu hususun bir kanun teklifi mahiyetinde hazırlanması gerektiğini bildirmiştir. Başvekâlet de lüzum görüldüğü takdirde gerekli işlemin yapılması konusunda Hariciye Vekâleti'ne talimat vermiştir (10 Haziran 1925) (BCA, MUAMELAT 030.10.00: 136.974.08, L.2).

Ancak bu konuda Başvekâlet tarafından Maliye Vekâleti'ne bir cevap verilmemişti. Bunun üzerine, Maliye Vekâleti tarafından aynı konu ile ilgili olarak Başvekâlet'e tekrar bir tezkere gönderilmiştir (1 Ağustos 1925) (BCA, MUAMELAT 030.10.00: 136.974.08, L.3).

Başvekâlet de Hariciye Vekâleti ile yapılan yazışma hakkında Maliye Vekâleti'ne 8 Ağustos 1925 tarihinde bilgi vermiştir. (BCA, MUAMELAT 030.10.00: 136.974.08, L.3).

Aynı dönemde Mösyö Stophan Stanitch'in de Harp Kazançları Vergisi'ni ödeyip ödememesi de gündeme gelmiş ve Hariciye Vekâleti İstanbul Murahhaslı̆̆ tarafından konu ile ilgili olarak İstanbul Vilayeti'nden bilgi talep edilmişti (30 Eylül 1925). Ancak daha önce Maliye Vekâleti tarafından, yabancıların ödemesi gereken Mükellefiyet-i Nakliye-i Askeriye Vergisi'nin bildirilecek en son habere kadar tahsil edilmesi tehir edilmişti. Yalnız bu durum antlaşma yapılan devletler tebaasına münhasırdı. Mösyö Stophan Stanitch ise, antlaşma yapılan devletler tebaasından değildi. Bu nedenle İstanbul Defterdarlığı tarafından İstanbul Valiliği'ne, adı geçen kişiden Mükellefiyet-i Nakliye-i Askeriye Vergisi'nin tahsil edilmesinin zaruri bulunduğu, Harp Kazançları Vergisi'nin tahsili hakkında da tahkikat ve tetkikat yapılmakta olduğu ve bunun neticesi hakkında bilgi verileceği bildirilmiştir. İstanbul Valiliği de konu hakkında 8 Aralık 1925 tarihinde Hariciye Vekâleti İstanbul Murahhaslığı'na bilgi vermiştir (BOA, HR. İM 
168: 87, L.1).

Ancak Mösyö Stophan Stanitch'in Harp Kazançları Vergisi verip vermeyeceği meselesi bir neticeye ulaşmamıştı. Bundan dolayı Sırp, Hırvat ve Sloven temsilciler tarafından icap eden tahkikatın ikmal edilerek, neticesinin acele olarak bildirilmesi, Hariciye Vekâleti İstanbul Murahhaslığı'ndan tekrar talep edilmiştir. Bunun üzerine konunun çözüme kavuşturulması, Hariciye Vekâleti İstanbul Murahhaslığı'nca 18 Ocak 1926 tarihinde İstanbul Valiliği'nden istenmiştir (BOA, HR. İM 168: 87, L.2).

\section{SONUÇ}

I.Dünya Savaşı esnasında, gayri meşru yoldan kazanç elde etme yaygınlaşmış ve bu olay ticari hayatta bir yozlaşma meydana gelmesine sebep olmuştur. Bunun üzerine devlet tarafından karaborsacıllı̆ı̆n önüne geçmek için bazı tedbirler alınmıştır. Bunların başında 24 Mayıs 1917 tarihinde 281 Numaralı İhtikârın Men'i Hakkında Geçici Kanun'un kabul edilerek, uygulamaya konulması gelmektedir. Ancak bu geçici kanunun uygulanması kendisinden beklenen neticeyi vermemiştir. Böylece devlet hukuki yollarla, ticaret erbabı tarafından yapılan suiistimalin önüne geçememiştir. Bunun üzerine devlet bu kazançlardan vergi alma yoluna gitmiştir. İlk önce 4 Nisan 1918 tarihli ve 126 numaralı Harp Kazançları Vergisi'nin Temin-i tahsili İçin Tedabir-i evveliyeyi muhtevi kanun kabul edilmiştir. Daha sonra da merkezi hükümet tarafından 14 Aralık 1919 tarihli Harp Kazançları Vergisi Hakkındaki Kararname yayınlanmıştır.

Ancak merkezi hükümet tarafından hazırlanan 1920 senesinin Mart ve Nisan aylarına ait geçici bütçeye eklenen bir madde ile vergi mükelleflerinden, Harp Kazançları Vergisi'nin tahsil edilmesi ertelenmiştir. Bu nedenle adı geçen verginin tahsil edilmesi, merkezi hükümet tarafından gerçekleştirilememiştir.

Harp Kazançları Vergisi'nin tahsil edilmesi konusunda Türkiye Büyük Millet Meclisi Hükümeti tarafından da bazı hukuki düzenlemeler yapılmıştır. Bunun neticesinde de Harp Kazançları Vergisi, ilk defa devletin 1922 yılı Gelirler Bütçesi'nde yer almıştır. Harp Kazançları Vergisi'nin Dolaysız Gelir Vergisi içindeki oranı 1922' de \% 2.06, 1923' de \% 2.48, 1924' de \% 3.41 ve 1925 yılında da \% 1.87 olmuştur. Bu verginin 1922-1925 yılları arasında Dolaysız Gelir Vergisi içindeki oranı da \% 2.51'dir. Devletin Gelirler Bütçesi'nde adı geçen verginin, beş yıllık sürede toplam tahsilât miktarı da 3.850 .000 lira olarak tespit edilmiştir.

Görüldüğü gibi Harp Kazançları Vergisi Kararnamesi yayınlandıktan iki yıl sonra uygulamaya geçebilmiştir. Bu süre zarfında ülke önemli bir savaştan çıkmış, vergi mükelleflerinin bir kısmı yerlerini değiştirmiş, bir kısmı da yurt dışında kalmıştır. Bu gibi nedenler beklenen vergi miktarının tahsil edilmesini önlemiştir.

Ayrıca Maliye Vekâleti tarafından Harp Kazançları Vergisi Kararnamesi'nin bazı maddelerinin tefsir edilmesi Türkiye Büyük Millet Meclisi'nden talep edilmiş ve bu talepler meclisçe yerine getirilmiştir.

Milli Mücadele ve Cumhuriyet dönemlerinde, vergi mükellefleri tarafından, kendilerine tahakkuk eden Harp Kazançları Vergisi hakkında merkezi hükümet döneminde Maliye ve Dâhiliye Nezaretleri ile Şûrâ-yı Devlet'e, Cumhuriyetin ilk yıllarında da Maliye Vekâleti'ne ve Türkiye Büyük Millet Meclisi'ne bazı itirazlar yapılmıştır. Buralarda yapılan görüşmeler sonunda vergi mükelleflerinin talepleri çözüme kavuşturulmaya çalışılmıştır. Ancak çözüme kavuşmayan bazı mükellef talepleri de olmuştur. Mesela; Aydın İncir Müstahsilleri Kooperatifi Anonim Şirketi'nin, Harp Kazançları Vergisi'nin kapsamı dışına çıkmak talebi, sadece kanun mantığ1 içinde düşünülerek, Şûrâ-yi Devlet tarafından çözüme kavuşturulamamış ve ülkede 
yeni teşekkül etmekte olan bir kuruluşun gelişmesine destek olunmamıştır.

Bunun yanında hayır kuruluşlarından da, Harp Kazançları Vergisi'nin tahsil edilmesi gündeme gelmiş, ancak bu konuda ilgili kuruluşlar tarafından yapılan itirazlar, Türkiye Büyük Millet Meclisi tarafından çözüme kavuşturulmuştur.

Yine Harp Kazançları Vergisi, Türkiye ile müttefik olan yabancı devletlerin vatandaşlarından tahsil edilmemiştir. Buna rağmen Türkiye'nin müttefiki olmayan yabancı devletlerin vatandaşlarından, adı geçen verginin tahsil edilmesi yoluna gidilmiştir.

1930'lı yıllarda Harp Kazançları Vergisi'nden adlarına tahakkuk etmiş olan verginin, belli bir miktarını ödemiş, ancak devlete bu vergiden borcu kalmış olan gerçek ve tüzel vergi mükelleflerinin vergi borçları terkin edilmiştir.

Böylece ahlaki bozulmanın, ticari ve sosyal hayatta önemli çözülmelerin meydana gelmesine sebep olduğu görülmüştür. Bu sebeple devlet tarafından bunun önüne geçilmek için çeşitli hukuki düzenlemeler yapılmıştır. Osmanlı Devleti'nin son yıllarında yayınlanan Harp Kazançları Vergisi Kararnamesi bunun en güzel örneklerinden birisidir. 


\section{KAYNAKLAR}

\section{I.ARŞIV BELGELERI}

1.1.Başbakanlık Osmanlı Arşivi

Meclis-i Vükela Mazbataları (MV)

Dosya Numarası; 221 Gömlek Numarası;188.

Şûrâ-yı Devlet (ŞD)

Dosya Numarası; 2387 Gömlek Numarası;20, Dosya Numarası; 3154 Gömlek Numarası; 46.

\subsubsection{NEZARETLER}

\subsubsection{Dâhiliye Nezareti}

Dâhiliye Nezareti Emniyet-i Umumiye Müdüriyeti (BOA. DH. EUM. MH )

Dosya Numarası; 206 Gömlek Numarası; 102.

Dâhiliye Nezareti İdare-i Umumiye Müdüriyeti (BOA. DH. İ.UM)

Dosya Numarası; 3 Gömlek Numarası; 1.

Dâhiliye Nezareti Umûr-1 Mahalliye-i Vilâyât Müdüriyeti Belgeleri (DH. UMVM)

Dosya Numarası; 162 Gömlek Numarası; 83

\subsubsection{Hariciye Nezareti}

Hariciye Nezareti İstanbul Murahhaslığı (BOA. HR. İM)

Dosya Numarası;168 Gömlek Numarası; 87

Hariciye Nezareti Hukuk Müşavirliği İstişare Odası (BOA. HR. HMŞ. İŞO)

Dosya Numaras1; 204 Gömlek Numarası; 41

\subsection{Başbakanlık Cumhuriyet Arşivi}

\section{Bakanlar Kurulu Kararları (BCA. BKK)}

Fon Kodu; 030.18.01 Yer Kodu; 01.11.26, Fon Kodu; 030.18.01 Yer Kodu;05.33.11

Muamelat Genel Müdürlüğü (BCA. MUAMELAT)

Fon Kodu; 030.10.00 Yer Kodu; 06.31.29, Fon Kodu; 030.10.00 Yer Kodu; 20.114.19, Fon Kodu; 030.10.00 Yer Kodu; 80.525.09, Fon Kodu; 030.10.00, Yer Kodu; 135.968.05, Fon Kodu; 030.10.00 Yer Kodu; 135.968.08, Fon Kodu; 030.10.00 Yer Kodu; 136.974.08;

Müşterek Kararnameler (BCA. MK)

Fon Kodu; 030.11.01 Yer Kodu; 127.48.15

\section{KITTAPLAR}

Alaiye Belediyesi (1330-1331), Alaiye Belediye Meclisi Karar Defteri, Alaiye: (Yayınlanmamış el yazması nüsha.)

AKBIYIK, Yaşar (1999), Milli Mücadele'de Güney Cephesi, Ankara: Atatürk Araştırma Merkezi Yayınları. Başvekâlet Müdevvenât Müdüriyeti (1928): Düstur (Tertib-i Sani), Cilt: 9, İstanbul: Evkaf Matbaası

Başvekâlet Müdevvenât Müdüriyeti (1928): Düstur (Tertib-i Sani), Cilt: 10, İstanbul: Evkaf Matbaas1 Başvekâlet Müdevvenât Müdüriyeti (1928): Düstur (Tertib-i Sani), Cilt: 11, İstanbul: Evkaf Matbaas1 DEVELLIOĞLU, Ferit (1998), Osmanlıca Türkçe Ansiklopedik Lûgat, Ankara: Aydın Kitapevi Yayınları

DURU, Cihan-TURAN, Kemal-ÖNGEOĞLU, Abdurrahman (1982), Atatürk Dönemi Maliye Politikası, 1. Kitap, Ankara: Tisa Matbaacılık Sanayii Ltd. Şti.

ELDEM, Vedat (1994), Harp ve Mütareke Yillarında Osmanlı İmparatorluğu'nun Ekonomisi, Ankara: Türk Tarih Kurumu Basımevi

Harp Kazançları Vergisi Hakkında Kararname (1335), İstanbul: Matbaa-i Amire.

Harp Kazançları Vergisi Hakkındaki Kararnamenin Suver-i Tatbikiyesini Mübeyyin Talimatname (1335), İstanbul: Matbaa-i Amire.

KÖSTÜKLÜ, Nuri (1999), Milli Mücadele'de Denizli, Isparta ve Burdur Sancaklarl, Ankara: Atatürk 
Araştırma Merkezi Yayınları.

Meclis-i Ayan (1991), Zabıt Ceridesi, Cilt:1, Ankara: Türkiye Büyük Millet Meclisi Matbaası.

Meclis-i Mebusan (1992), Zabıt Ceridesi, Cilt:1, Ankara: Türkiye Büyük Millet Meclisi Matbaası Tahsil-i Emval Kanunu (1325): İstanbul: Matbaa-i Amire.

Ticaret ve Ziraat Nezareti (1329), Teşvik-i Sanayi Kanun-u Muvakkati, İstanbul: Matbaa-i Osmani TOPRAK, Zafer (1982), Türkiye'de Milli İktisat (1908-1918), Ankara: Yurt Yayınları.

Türkiye Büyük Millet Meclisi(1341), Kavanin Mecmuası, Cilt:1, İstanbul: Sabah Matbaası.

Türkiye Büyük Millet Meclisi(1338-1341), Kavanin Mecmuası, Cilt:2, Ankara: Türkiye Büyük Millet Meclisi Matbaası .

Türkiye Büyük Millet Meclisi(1338-1341), Kavanin Mecmuası, Cilt:3, Ankara: Türkiye Büyük Millet Meclisi Matbaası.

Türkiye Büyük Millet Meclisi(1970), Zabıt Ceridesi, Cilt:7, Ankara: Türkiye Büyük Millet Meclisi Matbaası.

Türkiye Büyük Millet Meclisi (1976), Zabıt Ceridesi, Cilt:18, Ankara: Türkiye Büyük Millet Meclisi Matbaasi.

\section{MAKALELER}

DEMIRYÜREK, Meral (2015, Sonbahar), “Savaştan Doğan Bir Tip: Harp Zengini” , Turkish Studies, Cilt: 10/16: 493-508.

Resmi Gazete (1926), "Kazanç Vergisi Kanunu”, Ankara: Türkiye Büyük Millet Meclisi Matbaası, Sayı:321: $1145-1154$.

Resmi Gazete (1934), "Vergi Bakayasının Tasfiyesine Dair Kanun”, Ankara: Başvekâlet Matbaası, Sayı:2750: 4126-4128.

\section{TEZLER}

TEZCAN, Cezmi (2005), Tekalif-i Harbiye ve Tekalif-i Milliye Örneklerinde Savaş Dönemlerinde Mali Politikalar, Ankara: Ankara Üniversitesi Türk İnkılâp Tarihi Enstitüsü: (Yayınlanmamış Doktora Tezi.) 


\section{EKLER}

Ek 1:

Harp Kazançları Vergisinin Temin-i tahsili İçin Tedabir-i evveliyeyi muhtevi kanun (Düstur 1928: 10/422-423).

Madde 1: Memalik-i Osmaniye Dâhilinde icra-yi muamele eden bilumum anonim şirketler ile anonim şeklinde olan kooperatif ve sermayeleri eshama münkasım komandit şirketler 31 Kanun-u evvel 1333' de yahut muahhar bir tarihte hitam bulan sene-yi ticariyelerine ait temettuat-1 safiyelerini tevzi edecekleri sırada zirde gösterildiği veçhile hususa bir ihtiyat akçesi teşkil etmeye mecburdurlar. Şöyle ki; Mezkûr şirketlerce zikrolunan sene-yi ticariyeye mahsus tanzim edilen bilanço mucibince temettuat-1 safiye olmak üzere tebeyyün eden meblağdan.

Evvelen; tediye edilmiş sermayenin faizi ile hisse-i temettu mukabili olmak ve her ikisinin mecmuu iş bu sermayenin yüzde on beşini tecavüz etmemek üzere meclis-i umumilerince tensip olunacak miktar.

Saniyen; nizamnameleri mucibince adi ihtiyat akçesi (nizamnamelerinde musarrah değil ise temettuat-1 safiyenin nihayet yüzde beşi derecesinde).

Salisen; müessisleri ile meclis-i idare azaları ve müdür ve memurlara hisse-i temettu veya ikramiye veya cihet-i hayriyeye iane olarak itası nizamnameleri iktizasından olan mebaliğ.

Rabien; tesisat-1 iptidaiye imhası karşılığı (nizamnamelerinde musarrah değil ise demirbaş eşya kıymet-i asliyesinin nihayet yüzde onu ve emval-i gayrimenkule kıymet-i asliyesinin nihayet yüzde ikisi) tefrik edildiğinden sonra üst tarafını harp kazançları üzerine bir vergi tarhı kanun-u mahsus ile tekerrür ettiği takdirde tahakkuk edecek olan vergi borçlarının temin-i tediyesi zımninde hususa bir ihtiyat akçesi olmak üzere tefrik ve hıfz etmeğe mecburdurlar. Ancak iş bu mecburiyet 1333 senesi zarfında teşekkül etmiş olan şirketlerde miktar-1 mezkurun yalnız nısfına şamildir.

Madde 2: Birinci madde mucibince ihtiyaten tevkif olunacak mebaliğin faizi şirket hesabına işlemek üzere nakden yahut şirketçe arzu edildiği takdirde Devlet-i Osmaniye'nin faizli eshamına tahvil edildiğinden sonra bir bankaya tevdi edilmesini hükümet talep edebilir. Bankanın intihabı hükümetin kabulüne iktiran etmek şartıyla alakadar olan şirketlere aittir.

Madde 3: İş bu kanunun neşrinden sonra fesih olunan şirketlerden aranılacağı muhtemel olan verginin dûyun-u saireye tercihen temin-i tahsiline medar olmak üzere mezkur şirketlerin bilcümle mevcudat ve matlubatından birinci maddede gösterilen hudut dairesinde miktarını hükümet ihtiyaten tevkif eder.

Madde 4: Birinci madde mucibince hususa ihtiyat akçesinin emr-i teşkilinde iş bu kanunun ahkamına muhalif harekette bulunan şirketlerin meclis-i idare azasıyla müdür ve muhasebecilerinden rüyet-i hesaba memur müfettişlerinden her biri derece-i fiillerine göre bir haftadan bir seneye kadar hapis ile mücazat görecekler ve bu hareketlerinden dolayı karşlıksız kalan vergiyi de mesuliyet-i müştereke-i müteselsile ile zamin olacaklardır.

Madde 5: İş bu kanun ahkamı Memalik-i Osmaniye'de ifa-yi ticaret edip merkezleri diyar-1 ecnebiyede bulunan şirketlerin dahildeki şubeleri hakkında dahi tatbik olunur.

Madde 6: Birinci maddede zikrolunan şirketlerden gayri şirketler harp kazançları vergisiyle mükellef olabilecek efraddan mezkur verginin temin-i istifası zamanında münasip göreceği tedabiri ittihaza maliye nazırı mezundur.

Madde 7: İş bu kanun neşrinin ferdâsından itibaren meri'yy-ül icrâdır.

Madde 8: İş bu kanunun icrasında adliye ve maliye nazırları memurdur.

Meclis-i Ayan ve Mebusanca kabul edilen iş bu layihanın kanunuyetini ve kavanini devlete ilavesini irade eyledim. 22 Cemadil Ahire 1336/ 4 Nisan 1334 


$\begin{array}{lll}\text { Maliye Nazırı } \quad \text { Adliye Nazırı } & \text { Sadrazam } \\ \text { Cavit............................Halil } & \text { Mehmet Talat }\end{array}$

\section{EK 2:}

Harp Kazançları Vergisi Hakkında Kararname (Harp Kazançları Vergisi Hakkında Kararname 1335: 1-24; Düstur 1928: 11/495-511).

Mukaddeme

Verginin Tarifi ve Devre-i Tatbikiyesi

Madde 1: Harb-i umumi esnasında istihsal olunan temettuat-1 fevkalade üzerine "Harp Kazançları Vergisi" namıla bir defaya mahsus olarak fevkalade bir vergi tesis edilmiştir. Bu vergi $1332^{10}$ "1918" senesi kanun-u evvel nihayetine kadar hitam bulan son üç sene-i ticariye zarfında vuku bulan temettuat-1 fevkalade üzerine tarh olunur.

Birinci Fasıl

Muafiyet

Madde 2: Fıkra-i atide muharrir erbab-1 temettuat iş bu vergiden muaftırlar.

1.Dükkan ve mağaza açmaksızın mahsulatını çiftliğinde ve yahud şehir ve kasabalarda veya Pazar yerlerinde füruht eden çiftlik eshabı ve bir sene zarfında satmış oldukları tütün esmânı yüz liradan dûn olan tütün zürra ile sair bilumum zâri ve kendi hayvanatını besleyen mandıra sahipleri ve çoban ve bağcllar ve bahçıvanlar.

2.Kendi hesaplarına icra-yi ticaret etmemek şartıyla müessesat-1 hususiyede ve efrâd-1 hizmetlerinde maktu maaş veya ücretle müstahdem olanlar.

3.Kendi el emekleriyle tedarik-i maişet eden bilumum amele ve işçiler (Bunlardan hamal ve arabacılar istisnaen dokuzuncu ve muhtelif limanlar arasında seyr-ü sefer eden kayıkçılar onuncu madde mucibince maktu vergi ile mükellefdirler.)

4. Müellif ve muharrirler, ressamlar, heykeltıraşlar, bestekarlar, kompozitör mühendisler, mimarlar, tabipler, dava vekilleri, cerrahlar, ebeler, dişçiler, baytarlar ve alelumum meziyyâtı ilmiye ve fenniyeleriyle iktisab-ı maişet edenler (dava vekillerinin hukuk müşavirliği ücreti olarak herhangi bir müesseseden senevi aldıkları meblağ beş yüz liradan ziyade ise fazlası harp temettuatı addolunacağı gibi, mühendisler ve mimarların deruhte eyledikleri inşaat beş bin lirayı tecavüz eylediği takdirde fazlasından müstahsil temettu dahi harp temettuatından addedilir.)

5.Matbaacılar.

6.Taşocakları işletenler.

7. Aşar ve rüsum-u saire mültezimleri.

8.Balık sayyâdları

9.Bedel-i icarı senevisi 3500 kuruşu tecavüz etmeyen değirmenleri işletenler.

10. Sevahilde ve demiryolu istasyonlarında bulunanlar müstesna olmak üzere nüfusu iki binden dûn olan karyelerin ahalisi.

11.Son harpte düşman tarafından işgal edilen mahallerden hicret edenler ile alelıtlak ahir mahallere nakil ve tehcir edilenler.

12.Harik ve hayat sigorta şirketleri (nakliyat sigorta şirketleri on beşinci madde mucibince vergiye tabidirler.) 
Madde 3: Harp esnasında yapılan istikraz-1 dahili tahvilatını bidayeten imza zamanında başa baş olmak üzere iştirâ edenlerin iş bu istikraza tahsis ettikleri temettuat-1 fevkaladeleri harp kazançları vergisinden muaftır.

İkinci Fasıl

Harp Kazançlarının Suret-i Tayini

Madde 4: Anonim ve kooperatif ve eshamlı komandit şirketlerinin son üç sene-yi ticariyeleri zarfında istihsal eyledikleri temettuat-ı safiye de harp kazancı olup olmadığı vech-i ati üzere tayin olunur

İş bu şirketlerin müddet-i mükellefiyetleri olan üç sene-yi ticariyeden her biri için tanzim etmiş oldukları bilançolar mucibince tebeyyün eden temettuat-ı safiyelerinden evvela nizamnameleri mucibince senevi tediyesi lazım gelen faiz (Bu cihet nizamnamede musarrah değilse sermayenin tediye edilmiş kısmı üzerinden azami yüzde beş derecesinde faiz hesap olunur.), saniyen nizamnamelerinde muayyen alelade ihtiyat akçesi miktar-1 seneviyesi, salisen vech-i tahsisleri nizamnamede musarrah mebâliğ, rabien tesisat-1 ibtidaiye imhası karşllığ (nizamnamelerinde muharrir değilse demirbaş eşya için her sene kıymet-i asliyelerinin azami yüzde onu ve emval-i gayrimenkule için kıymeti asliyelerinin azami yüzde ikisi), hâmisen hisse-i temettu olmak üzere sermayenin tediye edilmiş kısmı üzerinden senevi yüzde beş bilhesap tenzil edildikten sonra üst tarafı temettuat-ı fevkalade itibar olunur. Temettuat-ı safiyenin hesabında dahi hususat-1 atiye nazar-1 itibara alınır.

1. Nizamnameleri mucibince hissedarına tediye olunan veya tediye edilecek olan faizler masraf hesabına geçildikten sonra temettuat-ı safiye istihraç edilmiş ise iş bu faizlerin yekûnu temettuat-1 safiyeye zam olunur.

Nizamname ile muayyen tesisat-ı ibtidaiye imhası karşılığı balada muharrir olan miktarları ve 1 Kanun-u sani 1916 tarihinden sonra teşekkül eden şirketlerin senevi ifraz olunan ihtiyat akçesi temettuat-ı safiyenin yüzde beşini tecavüz etmiş ise tecavüz eden miktarlar iadeten temettuat-1 mezkureye ilave edilir.

3. Mezkur şirketlerin müdür ve meclis-i idare azası ile müessislerine temettuat-1 safiye tebeyyün ettirilmezden evvel aidat ve ikramiye veya diğer bir nam ile masraf kayıt edilerek akçe verilmiş ise bunlar dahi temettuat-1 safiyeye zam olunur.

Tecil-i Duyun Kanunu mucibince imhal edilmiş matlubatından zarar kayıt edilmiş olanlarının bilahare vuku bulan tahsilatı tahsil olunduğu senede kar kayıt edilmiş ise mezkur seneye kar kayıt olunur.

5. Mazbatalı mazbatasız tekalif-i harbiye matlubatı zarar kayıt edilmiş ise iadeten kar kayıt olunur.

6. Bilançonun hin-i tanziminde şirket uhdesinde bulunan emvali gayrimenkuleye vaktiyle satın alınmış oldukları fiyattan dûn kıymet takdir edilmez.

7. Bilançonun hin-i tanziminde emtia-yi ticariyeye mal oldukları fiyattan dûn fiyat takdir olunamaz.

8. Mevcud-u sandık olan evrak-ı nakdiyenin altına tahvil için verilmiş olan akçe farkları zarar kayıt edilmiş ise temettuat-ı safiyeye zam edilir.

9. Şirketin düşman tarafından istila edilen mahallerdeki matlubatı zarar kayıt edilmiş ise makbuldür.

10. Şirketin tehcir edilen eşhas zimmetindeki matlubatı zarar kayıt edilmiş ise makbuldür. Fakat bilahare tasfiye komisyonları marifetiyle istifa olunan matlubat kar kayıt edilmiş olmak lazım gelir.

11. İrs, hibe, ikramiye isabeti ve alelumum sigorta bedeli gibi mükellefin muamelat-1 
ticariyesine taalluk etmeyen kazançları temettuat-1 safiyeye zam edilmek icap etmez.

12. Umur-u müessesat-1 hayriyeye vuku bulan teberruat ve ianet masraf kayıt edilmiş ise makbuldür.

Madde 5: Müddet-i mükellefiyet olan üç sene-yi ticariyeden birinde bir şirketin muamelatı kar yerine zararla kapanmış ise iş bu zarar diğer senelerin karından evvel be evvel mahsup olunur.

Madde 6: Aynı mükellefin muhtelif teşebbüsatından husule gelen temettuatı üzerine tarh edilecek Harp Kazançları Vergisi'ni iş bu temettuatın mecmuuna nazaran tatbik etmek caizdir. Ancak bu takdirde kendi nefine olarak bilumum teşebbüsatını ihbar ile hesabatının cemini talep etmek mükellefe aittir.

Madde 7: Kollektif ve adi komandit şirketlerle eşhas-1 münferideden matruh temettü vergilerinin aslı senevi 2.500 kuruşu tecavüz edenlerin temettuat-1 safiyeleri ber vech-i ati hesap edilir.

1332, 1333, 1334 senelerinden her birinde mükellefe tarh edilmiş olan temettu vergisinin aslı otuz üçe darp ile hasılı darba evvelen iş bu hasılı darbın rabii, saniyen senevi maktuen üç yüz elli lira hesabı ile bin elli lira zam edilmek sureti ile bulunacak rakam mükellefin mezkur seneler zarfındaki temettuat-ı adiyesi itibar olunarak bu seneler için mükellefin tanzim etmiş olduğu bilançolar mucibince tebeyyün eden temettuat-1 safiye mecmuundan bi-tenzil mütebakiyesi harp kazançları vergisine tabi tutulması iktiza eden üç senelik fevkalade temettuatı meydana çıkarmış olur. Bu kısım mükellefinin temettuat-ı safiye ve fevkaladelerinin hesabında dördüncü maddenin 4 ile 12 numaralı fıkralarında gösterilen hususat nazar-ı itibara alınmakla beraber masarif-i zatiye ve beytiyelerini ticarethanenin masrafına kayıt eyledikleri tebeyyün ettiği takdirde de iş bu masarif yekûnu temettuat-1 safiyeye zam edilir. 5'nci ve 6'ınc1 Maddelerin ahkamı iş bu madde de muharrir mükellefin hakkında dahi tatbik olunur.

Üçüncü Fasıl

Maktu ve Müterakki Vergiler

Madde 8: Harp Kazançları Vergisi maktu ve müterakki olmak üzere iki nevidir.

Vergi; Mevadd-ı atide gösterildiği üzere kavanin-i mahsusasına tevfikan istifa edilmekte olan bazı tekalif ve rüsumun bir veya birkaç misli derecesinde tarh olunan fevkalade vergidir.

Müterakki Vergi; Temettuat-1 adiyeye nispetle tebeyyün eden temettuat-1 fevkalade üzerinden nispet-i müterakkiye ile tarh olunan fevkalade vergidir.

Birinci Kısım

Maktu Vergiler

Madde 9: 1334 senesinde namına tahakkuk ettirilen temettu vergisi 2.500 kuruşu mütecaviz olmayanlar maktu vergi ile mükellef tutulurlar. Muafiyeti ikinci maddede gösterilenler müstesnadır.

Maktu vergi; temettu vergisi 1.500 kuruşu mütecaviz olmayanlar için mezkur verginin üç misli ve 1.500 kuruştan ziyade ve fakat 2.500 kuruşu gayri mütecaviz olanlar için mezkur verginin altı mislidir. İş bu maktu verginin tayininde temettu vergisine ilaveten istifa olunan munzam vergiler nazarı itibara alınmaz.

Madde 10: Maden ve orman işletenler, müskirat ameleleri, müskirat ve tütün ve enfiye bayileri ile muhtelif limanlar arasında sefer eden kayıkçılar 1332, 1333 ve 1334 seneleri zarfında tediye ettikleri rüsumun birer misli kadar bir meblağı harp kazançları vergisi namıla tediyeye mecburdurlar. İş bu vergi devair-i müteallikası tarafından tanzim ve cihet-i maliyeye tevdi olunacak defatire tevfikan tarh olunur.

İkinci Kısım

Müterakki Vergi 
Madde 11: Anonim, kooperatif ve eshamlı komandit şirketlerin 4. ile 6. Maddelere tevfikan tebeyyün ettirilecek olan temettuat-1 fevkaladelere zirde muharrir nispet-i müterakkiye ile harp kazançları vergisine tabi tutulur.

1.000 liraya kadar olana temettuat-1 fevkaladeden \% 5

1.000 'den ziyade olan temettuat-1 fevkaladenin 1.000 lirası nispeti mahsusasına tabi olmak üzere;

1.001'den 5.000 liraya kadar olan kisımdan $\quad \% 10$

001'den 10.000 liraya kadar olan kisimdan $\quad \% 15$

10.001 'den 25.000 liraya kadar olan kisimdan $\quad \% 20$

25.001'den 50.000 liraya kadar olan kisımdan $\quad \% 30$

50.001 'den 100.000 liraya kadar olan kisimdan $\quad \% 40$

100.001 'den 250.000 liraya kadar olan kısımdan $\quad \% 50$

250.001 'den yukarısı için $\% 60$

Madde 12: Kolektif ve adi komandit şirketlerle eşhas-1 münferidenin 7'nci Madde mucibince tebeyyün edecek temettuat-1 fevkaladeleri ber vech-i ati nispeti müterakkiye üzerinden vergiye tabi tutulur.

1.000 liraya kadar olanlardan

$\% 10$

1.000 liradan ziyade olanların 1.000 lirası nispet-i mahsusasına tabi olmak üzere

1.001 'den 5.000 liraya kadar olan kısımdan $\quad \% 15$

5001'den 10.000 liraya kadar olan kisimdan $\quad \% 20$

10.001 'den 25.000 liraya kadar olan kisımdan $\quad \% 25$

25.001'den 50.000 liraya kadar olan kısımdan $\quad \% 30$

50.001 'den 100.000 liraya kadar olan kisimdan $\quad \% 40$

100.000 liradan yukarisindan $\quad \% 50$

13: Anonim ve eshamlı komandit şirketlerinin müdür ve müessislerinin her birine temettuat-1 seneyeviyeden senevî ifraz ve ita edilen mebaliğ 500 lirayı tecavüz etmiş ise fazlası harp temettuatı olarak ad olunur. Ve madde-i sabıka mucibince kendilerinden müterakki vergi istifa edilir. Ancak bu yolda aldıkları mebaliğin kendi hususi ticarethaneleri hesabına kar geçirilmiş olduğu ispat ederlerse ayrıca vergiye tabi tutulmayıp ticarethanenin temettuat-1 umumiyesi üzerinden alınacak vergi ile iktifa edilir.

Madde 14: 11'nci veya 12'nci maddeler mucibince hesap olunan müterakki vergi mükellefin 1334 senesi zarfında tahakkuk ettirilmiş olan temettu vergisinin altı mislinden dûn olmadığı takdirde mezkur müterakki vergi temettu vergisinin altı misline iblağ olunur.

Madde 15: Nakliyat sigorta şirketlerinin 1916 Kanun-1 sanisinden itibaren Memalik-i Osmaniye dahilinde bir sene zarfında istifa ettikleri primlerin mecmuu üç evvelki senenin miktar-1 vasatiyesinden ziyade olduğu takdirde ziyadesi on birinci madde mucibince müterakki harp kazançları vergisine tabi tutulur.

Dördüncü Fasıl

Harp Kazançları Vergisi İle Mükellefiyeti İcap Eden Ahval-ı Mahsusa

Madde 16: Gerek haizi muafiyet olsun gerek olmasın atide muharrir muamelatı icra etmiş olanlar harp kazancına nail olmuş ad edilerek miktar-1 temettualarını kanaat bahs bir surette ispat edemedikleri takdirde atideki karain-i mahsusaya istinaden mükellef tutulurlar.

1.Cihet-i askeriye ile devair-i saireyi hükümete ve müessesat-1 resmiyeye gerek kontrata ile müteahhit sıfatıyla gerek adiyen pazarlıkla her nevi eşya ve erzak ve emtia satan veya nakliyat ve imalat icra edenler ile uhde-yi tasarruf ve isticarlarında bulunan merakıb-1 bahriye ve müessesat-1 sanaiyeyi hüsn-i rızalarıla cihet-i askeriyeye füruht ve devir edenler 
müteahhitlerin kontrat mucibince istifa ettikleri mebaliğin bir sene zarfındaki yekûnu veya pazarlıkla mal satanların bir defada tahakkuk eden istihkakları yüz liradan dûn olduğu takdirde vergiden muaf olup, 101 liradan 1.000 liraya kadar olduğu takdirde bunun \% 20'si, 1.001 liradan 5.000 liraya kadar olduğu takdirde bunun \% 15'i, 5.000 liradan ziyade olduğu takdirde, ziyadenin \% 10'u fevkalade temettü ad olunarak iş bu temettuat 12 . madde mucibince müterakki vergiye tabi tutulur.

2. Gerek hükümete ve gerek efrada ait olarak marifet-i hükümetle satılan emtia ve eşya ve hayvanatı satın almış olanlar kıymeti 200 lirayı tecavüz etmiş ise taşrada satılanların kıymetinin $\% 50$ 'si ve Dersaadet'te satılanların kıymetinin \% 30'u temettu-i fevkalade ad olunarak iş bu temettu dahi 12'nci maddede gösterilen müterakki vergiye tabi tutulur.

3. Meslekleri tacir veya komisyoncu veya dellal olmadığ $\breve{1}$ halde balada birinci fıkrada muharrir muamelata tavassut ederek müteahhit veya bayilerden komisyon veya dellaliye veya diğer bir nam ile akçe istifa etmiş olanlar.

$\mathrm{Bu}$ gibilerin her defa almış oldukları mebaliği on liradan fazla olduğu takdirde ziyadesi fevkalade temettu ad edilerek 12 'nci madde mucibince müterakki vergiye tabi tutulur.

4. Demiryolu hatları üzerinde vagon tedarik ve denizlerde vapur ve mavna isticar edenler.

Bu gibiler beher tam vagon için yüz lira ve vapurun beher tonu için üç ve mavnaların beher tonu için iki lira vergi ile mükellef tutulurlar.

5.Dördüncü fikrada muharrir vesaitle eşya-1 ticariye nakledenler ve ettirenler.

Bu gibilerden vagon ile nakledilen eşya için ton başına on beş ve vapur ile nakledilenler için ton başına dört buçuk ve mavna ile nakledilen eşya için ton başına üç lira vergi ahz olunur.

6.Kiymetli posta paketi ile emtia-i ticariyeyi dahil-i Memalik-i Osmaniye'de bir mahalden diğer mahalle naklettirenler.

Bunların beher defasında naklettirdikleri emtianın yüz lirayı tecavüz eden kıymeti üzerinden \% 10 vergi istifa olunur.

7. Emtia-i ticariyeyi Memalik-i Ecnebiye'ye ihraç edenler.

Bunların her defasında ihraç etmiş oldukları emtianın kıymeti yüz liradan fazla olduğu takdirde 5 Nisan sene 1333 tarihli kanun mucibince istifa edilmiş olan ihraç resminin nısfı derecesinde bir vergi istifa olunur.

Balada 1, 2, 4, 5 ve 6 numaralı fikralarda muharrir muamelatı ifa edenler, bunları başkaları hesabına icra etmiş olduklarını kanaat bahs olacak vesaikle ispat edebildikleri takdirde vergi kendilerinden aranılmayıp, muamele kimin hesabına yapılmış ise ondan istifa olunur.

8. Uhdelerine bin liralıktan fazla kıymetli emval-i gayrimenkule geçirenler.

$\mathrm{Bu}$ gibilerin teferrug etmiş oldukları emval-i gayrimenkulenin kıymetinin 1.000 liradan fazlası harp temettuundan mütehasıl ad olunarak 13'ncü maddedeki nispet-i müterakkiye üzerinden vergiye tabi tutulur. Şu kadarki harp kazancı ad olunan bedel-i ferağ diğer Karain ve ilamat ile harp kazancı vergisine tabi tutulmuş olan temettuun bir cüz'i olduğu ispat edildiği takdirde başkaca vergi alınmaz. Kezalik emval-i mezkureyi 1916 senesinden evvel bankalarda mevcut hesap- 1 carisindeki parasıyla aldığını veya uhdesindeki diğer bir mülkü satmak suretiyle elde ettiğini ve ikramiye isabeti, sigorta bedeli, peder veya zevcinden gayri bir kimseden vuku bulan hibe ve teberruat ile veya irsen kendisine intikal etmiş bir servet ile veya kısmen veya tamamen istidane edilmiş bir meblağ mukabilinde mubayaa ettiği vesaik-i mutebere ile ispat edenlerden dahi iş bu emvalden dolayı harp kazancı vergisi istifa olunmaz.

9. Bankalar marifetiyle bir defada memalik-i ecnebiyeye para ve esham nakil ve ihraç veya oralardan celp ve ithal edenler.

Bu gibilerin naklettikleri nukud ve eshamın bin lirayı tecavüz etmeyen miktarı muaf olmak üzere 1.000 liradan ziyade 5.000 liraya kadar olan kısmının \% 10'1, 5.000 liradan ziyade 10.000 
liraya kadar olan kısmının \% 7'i ve 10.000 liradan ziyadesinin \% 5'i harp kazancı ad olunarak iş bu temettuat 12 'nci madde mucibince müterakki vergiye tabi tutulur.

10. Zürra tarafından 1 Kanun-1 sani 1916 tarihinden sonra gerek reji idaresine ve gerek ihracat tüccarına satılan tütünlerin 1916 senesinden evvelki üç senenin rayiç-i vasatisi bulunarak, buna 1915 senesi ile daha evvelki senelerin mahsulatı için \% 25, 1916 senesi mahsulü için \% 50, 1917 senesi mahsulü için \% 100, 1918 mahsulü için \% 150'i zam ile bulunacak hasılı satış fiyatından bit-tenzil üst tarafı fevkalade temettü ad olunarak 12'nci madde mucibince müterakki vergiye tabi tutulur.

Madde 17: Her mahalde harp esnasında fevkalade temettu temin ettiği veya madde-i sabıkada muharrir olduğu veçhile para nakil eylediği tevatir derecesinde şayi olan kimselerden komisyonlar derece-i temettularını mübeyyin bir beyanname talep etmeye selahiyatdar olup, bu suretle talep olunan beyannameyi vermeyenler veya hilaf-1 hakikat beyanatta bulunanlar hakkında 21'nci maddede gösterilen komisyon marifetiyle tahkikat-1 lazıme icra olunarak tahakkuk ettirilecek vergi bir misli ceza ile tahsil olunur.

18: 16'ncı maddede muharrir Karain hakkında icap eden malumatı taalluk eden devair-i mülkiye ve askeriye ile nakliye şirketleri ve mezkur maddenin 3'ncü fikrasına mütedair malumatı alakadar olan şirketler ve eşhas ve bankalar Maliye Nezaretince tanzim olunacak talimatnamede gösterilen surette memurin-i maliyeye itaya mecburdurlar.

Madde 19: Üç sene-yi mükellefiyet zarfında harp kazancına malik olup da, beyanname ita etmeyen ve komisyonlarca resen vergi tarh olunmayan mükellefini, komisyonlara delailiyle ihbar eden ve ihbarları mertebe-i sübuta vasıl olarak vergi tarh olunan kimselerden tahsil olunacak cezanın nısfı ihbariye olarak muhbirlerine verilir.

Fasıl

Verginin Suret-i Tahakkuku

Madde 20: İş bu kararnamenin 4'ncü ve $12^{\prime}$ nci ve $15^{\prime}$ nci ve 16 'ncı maddeleri mucibince vergi ile mükellef olanlar mal memurlarına birer beyanname ita ve bu beyannameye taalluk eden sini-ni hesabiye bilançolarını imzaları tahtında musaddık birer suretini raptetmeye mecburdurlar. 4'ncü ve 12'nci maddeler mucibince vergi ile mükellef olanlar 16'ncı maddede muharrir muamelatı defterlerine ve bunlardan mutahassıl kazançlarını bilançolarına ithal etmişler ise muamelat-1 mezkure için ayrıca beyanname itasına mecbur değildirler. Beyannameler kararnamenin her mahalde neşir ve ilanı tarihinden itibaren nihayet bir ay zarfında ita olunmak lazımdır.

Madde 21: Mükellefin tarafından ita olunacak beyannamelerin tetkikiyle verginin tarhına ait muamelat temettu vergisi hakkındaki 30 Teşrin-i sani 1335 tarihli kararnamenin 21. maddesine tevfikan müteşekkil komisyonlarda icra olunur. Ancak iş bu komisyonlara taşrada kaza meclis-i idaresi azasından bir zat ilave olunur.

Muamelatı çok olan vilayet ve liva merkez ve merkezleriyle diğer mühim merakizde Maliye Nezareti'nin müsaade-i mahsusasıyla komisyonların adedi tezyid olunabilip bunların reisleri mecalis-i idarece rüesa-i memurinden intihap ve azaları belediye meclisleriyle ticaret odası azalarından ve ticaret odası bulunmayan yerlerde tüccar-1 mahalliyeden tefrik olunur. İş bu komisyonların adedi Dersaadet'te ve oradan teşkilatı mevcut olan mahallerde gösterilecek lüzum üzerine Maliye Nezareti'nce tayin ve riyasetlerine tahakkuk müfettiş ve memurlarıyla Memurin-i maliyeden diğer münasipleri intihap olunur.

Tarh komisyonlarının mukarreratı ekseriyet-i ara ile intihaz edilir. Komisyon mükellefini celp ve istima edebileceği gibi icabında gerek mükellefinden gerek devair-i resmiye-yi devletle müessesat-1 umumiyeden ve nakliyat şirketleriyle diğer şirket ve bankalardan ve tüccardan 
evrak ve vesaik dahi talep edebilir.

Komisyon mükellefinin yahut edminin huzuruyla defatir ve hesabatını ya bizzat veya memurin-i maliyeden bir veya müteaddit zevat marifetiyle tetkik ettirmek hakkına da haizdir.

Tetkik-i hesap esnasında muhalef-i ehl-i hibre ve mütercim dahi bulundurulabilir. Muntazam defter ibraz edemeyenlerle hiç defteri olmayanların temettuatını tahkikata müsteniden komisyon takdir eder. Mükellefin beyannamesine göre tahakkuk etmesi lazım gelen vergi komisyonca tebeyyün ettirilen miktardan \% 10 veya daha ziyade noksan zuhur ederse fark bir misli ceza ile tahakkuka zam olunur. Mamafih bu farkın sıhhatini ispat etmek memurin-i maliyeye aittir. Bu muamelatın hitamından yani komisyon mükellefin temettuat-1 fevkaladesi hakkında muktezi kanaat hasıl olduktan sonra buna terettüp eden vergi miktarı tayin ve mükellefe ba- ihbarname tebliğ olunur. İş bu ihbarnamede vergi müterakki ise;

1.Mükellefin tayin olunan temettuat-1 safiyesi

2. Adi temettu mukabili olarak tenzili icap eden miktarı

3.Harp kazançları vergisine matrah teşkil eden temettu-u fevkalade

4.Tarh olunan müterakki vergi miktarı irae olunur. Vergi karaine istinaden tahakkuk ettirilmiş ise hangi karineye göre ve ne miktar itibariyle teklif edildiği ayrıca işaret olunur.

Madde 22: Beyanname itasıyla mükellef olanlar müddet-i muayyene zarfında beyannamelerini vermedikleri takdirde bir ihtarname gönderilerek daha on beş gün mehil verilir. Bu müddet zarfında dahi beyannamelerini vermeyenlerin vergisi komisyonca resen takdir olunur. Ve bu halde tahakkuk ettirilen vergiye nısfı kadar da ceza zam olunur.

Madde 23: Maktu vergi ile teklif edilen bir kimse kendine ihbarname gönderilmezden evvel 20. madde mucibince beyanname ita eder. Ve beyannamesi mucibince tarh olunan vergi vaz olunan maktu vergiden ziyade bulunursa maktu verginin kaydı terkin ve eğer daha evvel istifa edilmiş ise beyanname üzerine tahakkuk eden vergiye mahsup edilir. Kezalik beyannamesi üzerine müterakki vergisi tahakkuk ettirilmiş olan bir mükellef karain-i mahsusa üzerine başkaca bir vergiye tabi tutulduğu halde iş bu karaine müstenit olan verginin matrahı olan muamelenin beyanname üzerine tarh olunan vergiye esas olan muamelatı meyanına dahil bulunduğunu ispat ederse, karain üzerinden tarh edilen verginin istifasından sarf-1 nazar olunur.

Madde 24: Harp kazançları vergisiyle hiç mükellef tutulmamış olan veyahut yeniden tebeyyün eden bir matrah üzerine ayrıca vergiye tabi olması icap eden bir mükellef aleyhinde kararnamenin tarih-i meriyetinden itibaren üç sene mürurundan sonra idare-i maliye bir güna teşebbüsat ve takibatta bulunamaz.

Madde 25: İkametgahları malum olmamakla beraber harpte kazançlar temin eyledikleri tevatür derecesinde şayi olanlar hakkında komisyonlarca tarh olunan vergiler itiraz müddetinin inkizasında memurin-i maliyece sulh mahkemelerine bil-müracaat giyaben tasdik ettirilmekle beraber emval-i mevcudeleri taht-1 hacze aldırılarak ve hükm-i giyabiye itiraz müddetinin hitamında kesb-i katiyet eyleyerek emval-i mahcuzenin füruhtuyla vergisi alelusul tahsil olunacaktır.

Madde 26: Tarh komisyonunca takdir olunan temettuat-1 fevkaladeye gerek mükellefin gerek memurun-i maliye ihbarnamenin tarih-i tebliğinden itibaren on beş gün zarfında itiraz edebilirler. İtiraz memurun-i maliye tarafından vaki olduğu halde tanzim olunacak itiraznamenin bir sureti derhal mükellefe tebliğ olunur. Ve cevapnamesini tanzim ve ita için kendisine müddet-i mezkureye ilaveten daha sekiz gün mehil verilir. Bu müddet zarfında mükellefin makbuz mukabilinde vereceği cevapnameyi mal memuru kendi itiraznamesine rapt etmeğe ve eğer müddet-i muayyene zarfında cevap vermemiş ise cevap vermediğini itiraznamesinin tebliğ ilmühaberi zirine zeylen tanzim olunan itirazname makbuz mukabilinde 
mahallenin en büyük mal memuruna ve varidat teşkilatı olan mahallerde mıntıka tahakkuk memuruna tevdi olunur.

Mükellef tarafından verilecek itiraznamenin mal memurunun ma-fevki bulunan makama veya doğrudan doğruya Maliye Nezareti'ne gönderilmesi caiz değildir. Fakat mükellef isterse itiraznamesiyle ona raptetmiş olduğu evrakın bir suretini Maliye Nezareti'ne gönderebilir. Bu takdirde mal memurundan almış olduğu makbuzun tarih ve numarasını itiraz arzuhalinde göstermeğe mecburdur. Makbuz numarasını göstermemiş olan itiraznameler merkezce nazar-1 itibara alınmaz.

Madde 27: Madde-i sabıka mucibince tanzim olunacak itiraznameler Maliye Nezareti'nde bu işe mahsus olarak teşkil edilecek olan merkez komisyonunda tetkik edilir. İş bu komisyon bir reisle on beş azadan mürekkep olup, reis ile azasının üçü defterdarlık veya onun fevkinde maliye memuriyetlerinde bulunmuş olanlar meyanında ve üçü diğer o derece mühim memuriyetlerde bulunmuş olanlar meyanında Maliye Nezareti'nce üçü mehakim reis veya azası mütekaidinin evsaf-1 lazımeye haiz olanları meyanından Adliye Nezareti'nce ve altısı Dersaadet Ticaret Odası azası veya mezkur odada mükayyıd tüccar meyanından ticaret odasinca intihap olunur.

Merkez komisyonu üç şubeye taksim ve her şubenin suret-i teşkili reis tarafından tayin edilir. Suret-i mahsusada ehemmiyeti olan bazı mesailin tetkiki reis tarafından heyet-i umumiyeye havale olunabilir. Şubelerce mukerreratı la-akall dört azanın vücuduyla ve ekseriyetle heyet-i umumiye kararları salisen ekseriyet ile ittihat olunur. Şebûatta tesavii ârâ vukuunda reisin bulunduğu taraf tercih olunur. Şubelerin mukerreratı aynı heyet-i umumiye mukerraratı gibi katidir. Fakat mukerrarat behemehal esbab-1 mucibeye müstenit olmak lazım gelir. Merkez komisyonunun mukerraratı aleyhinde yalnız nüfus-u memuriyetin suistimali takdirinde Şura-yi Devlet'e müracaat ile şikayet olunabilir. Fakat bu müracaat kesb-i katiyet eden verginin tehir-i tahsiline badi olamaz. Merkez komisyonu tarafeynin tahriren dermiyan edeceği itirazatını tetkik ile ittihazı karar edip, doğrudan doğruya tetkik-i hesabat ile mükellef değildir. Ancak pek mühim gördüğü bazı hususatın tetkiki için keyfiyetin maliye heyet-i teftişiyesine havalesini heyet-i umumiye kararıyla Maliye Nazırı'ndan talep edilecektir.

Tarh komisyonlarıyla merkez komisyonunun teşkilat ve vezaifine ve reis ve azaya verilecek ücürete ait hususat Maliye Nezareti'nce talimatname ile tebeyyün edilecektir.

Madde 28: Verginin miktarı hakkında mükellef tarafından itiraz vukuunda yalnız tenzil talep olunan miktarın tahsili merkez komisyonunun kararına taliken tehir olunup, bakisi tekasit-i muayyenesinde tahsil olunur. Merkez komisyonunca tenzili kabul olunan miktar tenzili talep olunan miktardan dûn bulunduğu takdirde komisyon kararı mucibince ilaveten tahsili lazım gelen miktarı tekaside tabi tutulmayıp, kararın tebliğini müteakip hulul edecek ilk taksitte ve eğer taksitler kamilen geçmiş ise defaten lazım-el-tahsil olur.

Komisyonca kabul olunan tenzilat mükellefin iddia eylediği tenzilatın nısfından dûn olduğu takdirde farkının yani fazla talep edilmiş olan tenzilatın yüzde onu cezaen vergiye başkaca zam olunur. Mükellefiyetin esasına itiraz verginin miktarına itiraz gibidir.

Altıncı Fasıl

Verginin Suret-i Tahsili

Madde 29: Harp kazançları vergisinin maktu kısmı bir ay fasıla ile iki taksitte ve müterakki kısmı ikişer ay fasıla ile üç taksitte Tahsil-i Enval Kanunu'na tevfikan tahsil olunur. Askerlik verginin tahsiline mani değildir.

Madde 30: Anonim ve kooperatif ve eshamlı komandit şirketler namına tahakkuk eden vergi 4 Nisan 1334 tarihli Tedabir-i İhsariye Kanunu mucibince mevkuf tutulan meblağdan 
istifa olunur. Kafi gelmediği takdirde verginin bakiyesi ihtiyat akçesinden ve bu da kifayet etmezse ertesi senelerin temettuatından ve şirketin infesahı halinde mevcudundan tahsil olunur.

Madde 31: Fesih edilen şirket adi komandit veya kolektif bir şirket ise vergi borcu diğer şürekaya müracaat hakları olmak üzere mesul olan şürekadan tahsil olunur. Ve tevhit edilen şirketlerin borcu hala baki olan şirketten aranılır.

Madde 32: Merkez idaresi memalik-i ecnebiye de bulunan bir şirketin harp kazançları vergisine yalnız Memalik-i Osmaniye dahilindeki muamelat ve hesabatı esas ittihaz olunur. Böyle bir şirketin Memalik-i Osmaniye dahilinde müteaddit şubeleri olduğu takdirde bunların vergisi umumi acentenin bulunduğu mahalde tesviye edilir.

Madde 33: Harp kazançları vergisinden borcu olanların hazineden Dûyun-u Gayri Muntazama Kanunu'na tabi olmayan matlubatı olduğu takdirde harp kazançları vergisinden olan borçlarının nısfı iş bu matlubat ile takas ve mahsup olunabileceği gibi, harp kazançlarını umum sanayiye veya ziraiye veya nafia ile iştigal etmek üzere dahil-i Memalik-i Osmaniye'de müceddeden tesis olunan anonim şirketlerine sermaye olarak vazettiklerini yedlerinde bulunan mezkur şirketlere ait hisse senedatı ile ispat edenler dahi iş bu kazançların tabi olduğu vergiyi başa baş hesap olunmak üzere mezkur hisse senedatı ile ifa edebilirler.

Bu takdirde senedat-1 mezbureden name muharrir olanlar hazine-yi maliye uhdesine devir edilmek lazım gelir.

Yedinci Fasil

Ahkam-1 Cezaiye

Madde 34: Sahte ve mükerrer defter tanzimi veya defatir-i ticariyede tahrifat icrası gibi hile ve desâis istimali suretiyle temettuatını kısmen veya tamamen ketm eden bir mükellef ketm ettiği temettua ait vergisinin mikdarına göre 17 ve 22 'nci Maddeler mucibince itasına mecbur olacağı cezadan maada üç aydan üç seneye kadar hapis ile de mücazat edilir. İş bu hapis cezası kolektif ve adi komandit şirketlerde şirketin imzaya mezun şerik veya vekillerine ve anonim şirketlerde o mahiyete haiz diğer şirketlerde müdür ve muhasebecilerine veya tasfiye-i hesap memurlarına tatbik olunur. Ve anonim şirketlerle o mahiyete haiz olan diğer şirketlerde iş bu hapis cezasına sebep olan fiil-i irtikap edenlerden başkaca 25 liradan 5.000 liraya kadar ceza-yi nakdi alınır.

Kezalik efal-i mezkureye hariçten iştirak edenler iş bu hapis ve ceza-i nakdinin her ikisi ile mücezat edilirler.

Madde 35: 18. Madde mucibince Karain hakkında idare-i maliyeye itası lazım gelen malumat hiç verilmediği veyahud malumatı havi verilen evrak münderecatı tam ve hakikat-i hale muvafık olmadığı takdirde bu malumatı vermekle vazifedar olan memurin ile zabitan ve mebsubin-i askeriye üç aydan üç seneye kadar hapis edilmekle beraber sınıf-1 askeriyeye mensup olanlar tart ve diğerleri müebbeden veya muvakkaten memuriyetten mahrum edilirler.

Mükellefin hiyaneten hiç malumat vermeyen veyahut noksan veya geliş-i (güzel) malumat ita eden bir anonim veya eshamlı komandit veya kooperatif şirket ise mezkur şirket idaresinden 100 liradan 2.000 liraya kadar ceza-i nakdi ahz olunur. Ve noksan veya geliş-i (güzel) evrakı tanzim ve zirini imza eden şirket memurları hakkında bir haftadan üç seneye kadar hapis cezası hükmolunur. Mükellefin hiyaneten ticarethanesine taalluk eden mevad hakkında idare-i maliyeye malumat vermeye veyahut noksan veya gelişi (güzel) malumat ita eden şahıs tüccardan olduğu takdirde 25 liradan 1.000 liraya kadar ceza-i nakdi alınmakla beraber kendileri kezalik bir haftadan üç seneye kadar hapis edilirler. kolektif ve adi komandit şirketlerde bu cezalar müdür-i mesuller hakkında tatbik olunur.

Madde 36: İş bu cezalar ile harp kazançları vergisinden menbais tatbikat-1 saire-i kanuniye 
sulh mahkemelerinde icra olunur. Memurine müteallik deavide ahkam-1 umumiye bakidir.

Madde 37: Harp Kazançları Vergisinin tarh ve tetkiki vazifesiyle mükellef olanlar iş bu vazife dolayısıyla muttali olabilecekleri esrar-1 ticariyeyi ketme mecburdurlar. İfşa edenlerden 5 liradan 25 liraya kadar ceza-i nakdi alınır. Ve kendileri bir aydan bir seneye kadar hapis ile mücezat olunur. Memurinden iseler fazla olarak bir daha hizmet-i devlette istihdam edilmezler.

Hateme

Madde 38: İş bu Harp Kazançları Vergisi'nin tayini için yapılacak tetkikat diğer bir vergiye esas teşkil edemeyeceği gibi, bu vergiye her ne nam ile olursa olsun küsurat-1 munzama dahi ilave edilemez.

Madde 39: İş bu kararname tarih-i neşrinden itibaren meri'yy-ül icradır.

Madde 40: İş bu kararnamenin icrasına heyet-i vükela memurdur.

Meclis-i Umuminin içtimaında kanuniyeti teklif olunmak üzere iş bu kararnamenin mevki-i meriyete vaazını irade eyledim. 20 Rebi'ül Evvel 1338/14 Kanun-u Evvel 1335 